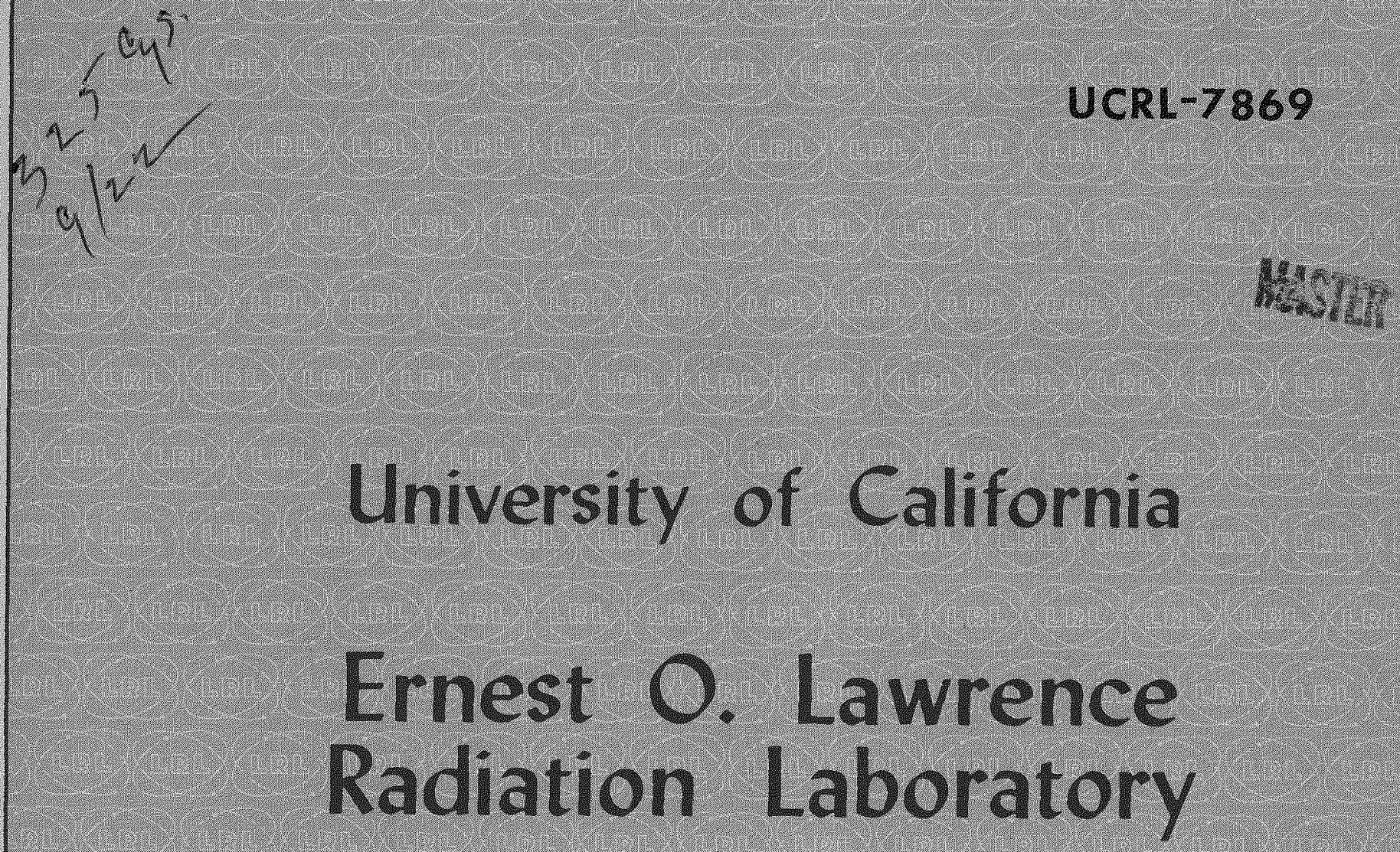

\title{
THE PROPERTIES OF A METASTABLE GAMMA-PHASE URANIUM-BASE ALLOY: U-7.5 Nb-2.5 Zr
}




\section{DISCLAIMER}

This report was prepared as an account of work sponsored by an agency of the United States Government. Neither the United States Government nor any agency Thereof, nor any of their employees, makes any warranty, express or implied, or assumes any legal liability or responsibility for the accuracy, completeness, or usefulness of any information, apparatus, product, or process disclosed, or represents that its use would not infringe privately owned rights. Reference herein to any specific commercial product, process, or service by trade name, trademark, manufacturer, or otherwise does not necessarily constitute or imply its endorsement, recommendation, or favoring by the United States Government or any agency thereof. The views and opinions of authors expressed herein do not necessarily state or reflect those of the United States Government or any agency thereof. 


\section{DISCLAIMER}

Portions of this document may be illegible in electronic image products. Images are produced from the best available original document. 
UCRL-7869

Metals, Ceramics and

Materials, UC-25

TID-4500 (30th Ed.)

\author{
UNIVERSITY OF CALIFORNIA \\ Lawrence Radiation Laboratory \\ Livermore, California \\ Contract No。W-7405-eng-48
}

THE PROPERTIES OF A METASTABLE GAMMA-PHASE

URANIUM-BASE ALLOY: U $-7.5 \mathrm{Nb}-2.5 \mathrm{Zr}$

C. A. W. Peterson

R. R. Vandervoort

May 13, 1964 
Printed in USA. Price Available from the office of Technical Services

U. S. Department of Commerce

Washington 25 , D.C. 


\author{
THE PROPERTIES OF A METASTABLE GAMMA-PHASE \\ URANIUM-BASE ALLOY: U-7.5 Nb-2.5 Z r \\ C. A. W. Peterson and R. R. Vandervoort \\ Lawrence Radiation Laboratory, University of California \\ Livermore, California \\ May 13, 1964
}

\begin{abstract}
The uranium-niobium-zirconium ternary system exhibits a series of solid solutions at high temperature. Addition of both niobium and zirconium stabilizes the body-centered-cubic gamma phase to a lower temperature. A study has been made of one particular ternary alloy, the $\mathrm{U}-7.5 \mathrm{w} / \mathrm{O} \mathrm{Nb}-2.5$ w/o Zr composition. The relationship of transformation characteristics of the alloy to its physical and mechanical properties has been determined. This weldable alloy is concluded to be an excellent material for engineering applications. Tensile yield strengths of 100,000 to 200,000 psi a re obtainable, with elongations of $12 \%$ to $4 \%$, respectively, depending on heat treatment.

\section{INTRODUCTION}

While gamma-stabilized uranium is of interest because of the more isotropic nature of the body-centered-cubic gamma phase and its amenability to heat treatment, the binary alloys of uranium-molybdenum, uraniumniobium, and uranium-zirconium that have been developed thus far each possess some shortcoming with respect to engineering applications. The gamma uranium-niobium alloys, for instance, have low yield strengths, causing them to creep or rupture under high loads; the gamma uraniummolybdenum alloys fail in a brittle manner under static or low-strain-rate loading in environments containing oxygen; the gamma uranium-zirconium alloys transform to very strong, hard alloys but they lack ductility at room temperature. In the gamma phase a balance of strength and stability at room temperature is obtained with a composition of $\mathrm{U}-7.5 \mathrm{w} / \mathrm{O} \mathrm{Nb}-2.5 \mathrm{w} / \mathrm{O} \mathrm{Zr}$.

Data available from studies of the isothermal gamma-phase reactions of the binary alloys ${ }^{1,2}$ and from work on the ternary equilibrium diagram of
\end{abstract}


uranium-niobium-zirconium ${ }^{3}$ have stimulated a detailed examination of alloys in the uranium-rich corner of the ternary system. A ternary gammaphase alloy with a nominal composition of $U-7.5 \mathrm{w} / 0 \mathrm{Nb}-2.5 \mathrm{w} / 0 \mathrm{Zr}$ has been developed as a result of this investigation. This alloy is not susceptible to stress cracking $^{4}$ in air or oxygen and can be heat treated to obtain a wide range of properties.

\section{EXPERIMENTAL PROCEDURE:}

The selection of the U-7.5 w/o Nb-2.5 w/o Zr composition for evaluation was based, in part, on the behavior of the binary uranium-niobium and uranium-zirconium alloys. It was desired to combine a sufficient amount of niobium for stabilizing the gamma phase with a sufficient amount of zirconium for strengthening. It was also desired to retain, as much as possible, the ductility which is characteristic of the binary uranium-niobium alloys.

Small arc-melted buttons as well as plate from $10-\mathrm{kg}$ and $100-\mathrm{kg}$ ingots were used to study the phase stabilities, isothermal transformations, and physical and mechanical properties of the alloy. The results of these studies, along with fabrication procedures and other pextinent information, are described below.

\section{Materials}

The highest purity materials available were used. Emphasis was placed on low interstitial impurities. Typical analyses of materials used are given in Table $\mathrm{I}$.

\section{Preparation of the Alloys}

The material which was used in the differential thermal analysis (DTA), isothermal experiments for the TTT curves, and hardness-versus-heattreatment studies was prepared in the form of $200-\mathrm{g}$ buttons. Ingots of approximately $2 \times 1 \times 0.375$ in. were formed in a water-cooled copper mold by arc-melting the charge in an argon atmosphere. Five remelts were made and the final ingot was homogenized in vacuum for 72 hours at $850^{\circ} \mathrm{C}$. The analyses of the ingots were substantially the same as the charges, i。e., 90 w/o uranium, $7.5 \mathrm{w} / \mathrm{o}$ niobium, and $2.5 \mathrm{w} / \mathrm{o}$ zirconium.

Ingots in the 8 - to $10-\mathrm{kg}$ range were arc-melted for physical and mechanical property samples. Sandwich-type electrodes of individual metal 
Table I. Typical analyses of materials used for uranium alloys.

\begin{tabular}{|c|c|c|c|c|c|c|c|}
\hline \multicolumn{2}{|c|}{$\begin{array}{l}\text { Uranium } \\
\text { (ppm) }\end{array}$} & \multicolumn{2}{|c|}{$\begin{array}{c}\text { Molybdenum } \\
\text { (ppm) }\end{array}$} & \multicolumn{2}{|c|}{$\begin{array}{l}\text { Niobium } \\
\text { (ppm) }\end{array}$} & \multicolumn{2}{|c|}{$\begin{array}{c}\text { Zirconium } \\
\text { (ppm) }\end{array}$} \\
\hline $\mathrm{C}$ & 35 & $\mathrm{C}$ & $190-200$ & $\mathrm{C}$ & 140 & $\mathrm{C}$ & $<600$ \\
\hline & 150 & $\mathrm{Si}$ & 100 & $\mathrm{Ta}$ & 1000 & $\mathrm{Fe}$ & 600 \\
\hline $\mathrm{Mg}$ & 21 & $\mathrm{Fe}$ & 50 & $\mathrm{Ti}$ & 300 & $\mathrm{Cr}_{r}$ & 87 \\
\hline $\mathrm{Ni}$ & 30 & $\mathrm{Cr}$ & 20 & $\mathrm{Fe}$ & 150 & $\mathrm{Mn}$ & 15 \\
\hline $\mathrm{Si}$ & 20 & $\mathrm{Sn}$ & 20 & $\mathrm{O}_{2}$ & 1000 & Al & 28 \\
\hline $\mathrm{Mn}$ & 35 & Mo & Bal。 & $\mathrm{N}_{2}$ & 750 & $\mathrm{O}_{2}$ & 600 \\
\hline $\mathrm{Pb}$ & $<4$ & & & $\mathrm{Si}$ & $<50$ & $\mathrm{~N}_{2}$ & 20 \\
\hline $\mathrm{Cu}$ & 20 & & & & $<10$ & $\mathrm{Ti}$ & 24 \\
\hline $\mathrm{Al}$ & $<11$ & & & $\mathrm{Nb}$ & Bal. & Hf & 100 \\
\hline B & $<0.4$ & & & & & $\mathrm{~Pb}$ & $<50$ \\
\hline $\mathrm{Ca}$ & 11 & & & & & $\mathrm{Si}$ & 50 \\
\hline \multirow[t]{2}{*}{$\mathrm{U}$} & Bal。 & & & & & $\mathrm{Ni}$ & 10 \\
\hline & & & & & & $\mathrm{Zr}_{\mathrm{r}}$ & $99.75 \%$ \\
\hline
\end{tabular}

strips, edge-welded into a $30 \times 1 \times 1$-in. compact, were thoroughly outgassed in vacuum at $850^{\circ} \mathrm{C}$ and arc-melted in argon. The 3-in.-diam ingot was quartered, rewelded into a new electrode, vacuum-outgassed, and arc-melted to another 3-in.-diam cylinder about 6 in. long. After surface-machining and cropping, the ingot was heated to $950^{\circ} \mathrm{C}$ in argon and hot-forged to $2-$ in. thick plate. This plate was then hot-rolled from $840^{\circ} \mathrm{C}$ to finished size (0.325-in.-thick plate), annealed at $840^{\circ} \mathrm{C}$ in a salt bath for $1 / 2$ hour, and cooled to room temperature in argon.

Commercial-size plates of approximately $100 \mathrm{~kg}$ were produced at the Bureau of Mines in Albany, Oregon. The electrodes for these melts were formed from laminations of bars of uranium and strips of niobium and zirconium. The welded assembly was arc-melted at a pressure of about 60 microns into a 4-in. -diam, water-cooled copper mold. The ingot was faced off and butt-welded to a similar ingot, forming a new electrode which was arc-melted into a 6-in.-diam ingot. This ingot was quartered, rewelded, and melted into a final 6-in.-diam ingot in a vacuum. 
The machined $90-\mathrm{kg}$ ingot was heated for $1-1 / 2$ hours in argon at $950^{\circ} \mathrm{C}$ and press-forged to a rectangular slab. The slab was hot-rolled at $840^{\circ} \mathrm{C}$ to a plate about $0.875 \mathrm{in}$. thick, then heated to $800^{\circ} \mathrm{C}$ in a salt bath and hotrolled to $0.625-\mathrm{in}$. plate. The final heat treatment consisted of a 1 -hour anneal at $950^{\circ} \mathrm{C}$ in argon followed by cooling in an argon-filled chamber to room temperature. Analyses of the $9-\mathrm{kg}$ and $90-\mathrm{kg}$ plates are given in Table II.

Table II. Analyses of $9-\mathrm{kg}$ and $90-\mathrm{kg}$ plate of $\mathrm{U}-7.5$ $\mathrm{w} / \mathrm{o} \mathrm{Nb}-2.5 \mathrm{w} / \mathrm{o} \mathrm{Zr}$ alloy。

\begin{tabular}{lcl}
\hline & $9-\mathrm{kg}$ plate & $90-\mathrm{kg}$ plate \\
\hline $\mathrm{Nb}$ & $7.4 \%$ & $7.3 \%$ \\
$\mathrm{Zr}$ & $2.5 \%$ & $2.5 \%$ \\
$\mathrm{C}$ & $55 \mathrm{ppm}$ & $100 \mathrm{ppm}$ \\
$\mathrm{O}_{2}$ & $40 \mathrm{ppm}$ & $35 \mathrm{ppm}$ \\
$\mathrm{N}_{2}$ & -- & $14 \mathrm{ppm}$ \\
$\mathrm{H}_{2}$ & -- & $18 \mathrm{ppm}$ \\
\hline
\end{tabular}

TRANSFORMATIONS

1. Differential Thermal Analysis

Standard 0.375 -in. $\times 0.250-$ in.-diam cylindrical samples were machined from homogenized $\left(72\right.$ hours at $\left.850^{\circ} \mathrm{C}\right) 200-\mathrm{g}$ button ingots. They were cycled from room temperature to $900^{\circ} \mathrm{C}$ and back to room temperature at a uniform rate of $85^{\circ} \mathrm{C}$ per hour. Figure 1 is a photograph of a chart recording a cycled run for pure uranium showing the sharp thermal peaks of the gammato-beta and beta-to-alpha transformations. Figure 2 is a photograph of a cycle made on a sample of $\mathrm{U}-7.5 \mathrm{w} / \mathrm{O} \mathrm{Nb}-2.5 \mathrm{w} / \mathrm{OZr}$, as wrought and gammaannealed.

In the ternary alloy the temperature of the gamma-phase transformation has been lowered substantially and the beta-phase reaction has been eliminated. The alloy transforms on cooling directly from gamma to alpha phase. The original gamma-phase transformation of the pure uranium now occurs at about $500^{\circ} \mathrm{C}$ in the ternary alloy. It is also very sluggish and drawn out and is not completed until the temperature has fallen to $363^{\circ} \mathrm{C}$. At room 

Differential Thermal Analysis of Pure Uranium and $\mathrm{U}-7.5 \mathrm{w} / \mathrm{O} \mathrm{Nb}-2.5 \mathrm{w} / \mathrm{O} \mathrm{Zr}$

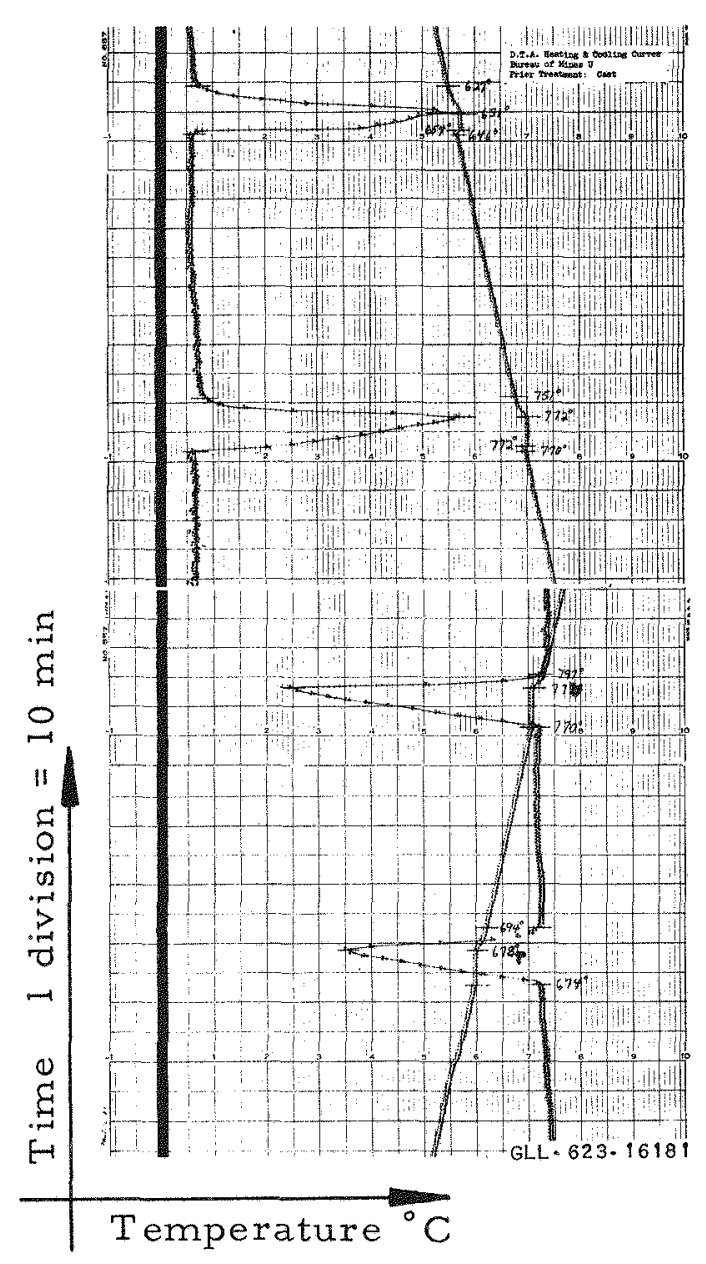

Fig. 1. Pure uranium.

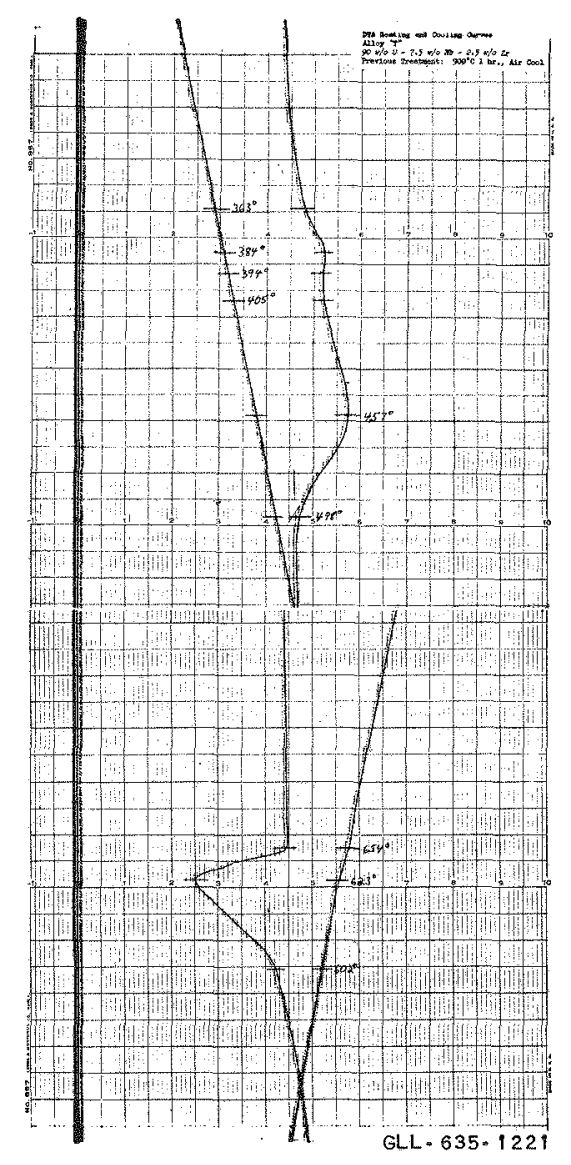

Fig. 2. U-7.5 w/o Nb-2.5w/o Zr. 
temperature, $\mathrm{x}$-ray analysis shows the alloy to be a mixture of alpha uranium and $\gamma^{\prime}$, a bcc niobium-rich solid solution. No delta phase corresponding to $\mathrm{UZr}_{3}$ was detected at this niobium concentration.

Results from thermal cycling of various samples made from different melts and processed under different conditions agree closely in the manner of the gamma phase transformation.

\section{Dilatometry}

The linear expansion and contraction of samples in the range from room temperature to $1000^{\circ} \mathrm{C}$ were determined. With the same heating and cooling rates used in the differential thermal analysis, a typical curve (Fig.3) for a sample of the $\mathrm{U}-7.5 \mathrm{w} / \mathrm{O} \mathrm{Nb}-2.5 \mathrm{w} / \mathrm{O} \mathrm{Zr}$ alloy from a $90-\mathrm{kg}$ hot-worked plate) was determined.

On heating, the alloy expands normally to $600^{\circ} \mathrm{C}$, at which point a very rapid expansion occurs to $640^{\circ} \mathrm{C}$. These points agree quite well with those from the DTA $\left(602\right.$ and $\left.654^{\circ} \mathrm{C}\right)$. During cooling the cycle is normal with a somewhat exaggerated contraction at about $375^{\circ} \mathrm{C}$. This point is considerably lower than that for the DTA $\left(500^{\circ} \mathrm{C}\right)$ and is probably due to the conditions of cooling and the temperature measuring sensitivity of the equipment used.

The average linear coefficients of expansion calculated from the chart are given in Table III.

\section{Isothermal Transformation}

The time-temperature-transformation or TTT curve is a familiar method of determining the gamma phase stability of the alloy under nonequilibrium conditions. In the present study the time of origin of transformation was estimated from the beginning of changes in electrical resistance, hardness, and microstructure. Figure 4 shows TTT curves assembled from the reaction data at the various isotherms using both the resistivity and hardness measurements. The agreement is quite good. In the upper regions from 500 to $600^{\circ} \mathrm{C}$ the microstructures agree quite well, but below $500^{\circ} \mathrm{C}$ metallographic results are difficult to interpret and hence the TTT curves are made without these data. The microstructures were identified in some cases by use of $x$-ray diffraction and in others by effects of chemical etchants. 


$$
\text { L }
$$




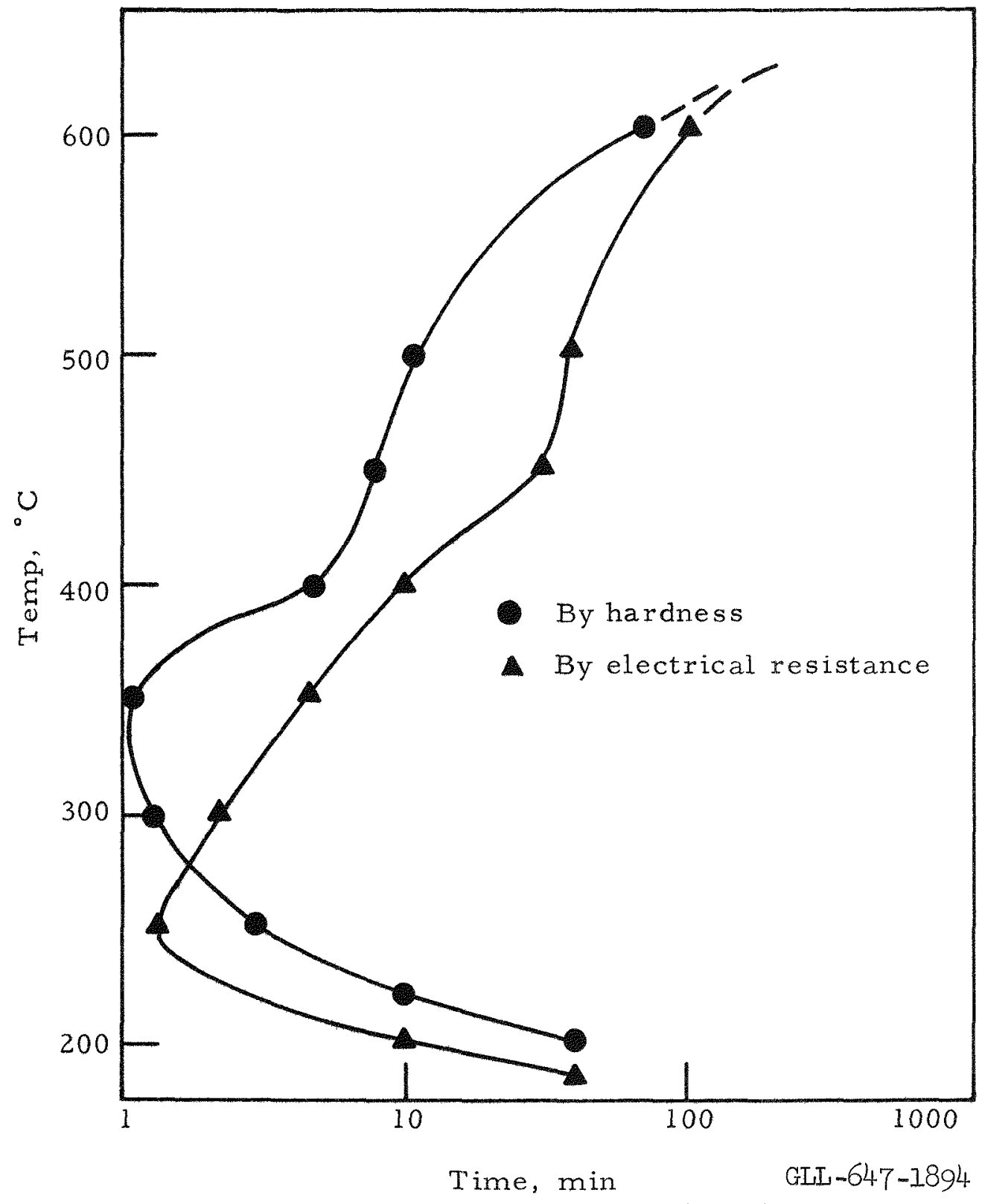

Fig. 4. Time-temperature-transformation (TTT) curves for $U-7.5 \mathrm{w} / \mathrm{o}$ $\mathrm{Nb}-2.5 \mathrm{w} / \mathrm{O} \mathrm{Zr}$. 
Table III. Coefficient of linear thermal expansion for $\mathrm{U}-7.5 \mathrm{w} / \mathrm{o} \mathrm{Nb}-2.5 \mathrm{w} / \mathrm{o} \mathrm{Zr}$ alloy.

\begin{tabular}{cc}
\hline $\begin{array}{c}\text { Temperature range } \\
\left({ }^{\circ} \mathrm{C}\right)\end{array}$ & $\begin{array}{c}\text { Coefficient of expansion } \\
\left(\text { in. } / \text { in. }{ }^{\circ} \mathrm{C}\right)\end{array}$ \\
\hline 20 to 300 & $14.8 \times 10^{-6}$ \\
600 to 635 & $124.7 \times 10^{-6}$ \\
640 to 1000 & $144 \times 10^{-6}$ \\
20 to 1000 & $16.9 \times 10^{-6}$ \\
\hline
\end{tabular}

The resistivity measurements were made at the temperature of trans formation after a direct transfer of the sample from the gamma annealing bath to the isothermal transformation bath. The equipment allows readings to be taken automatically in decades from I minute to 10,000 minutes. Immediate readout of resistivity changes as small as 0.0004 ohm is noted on semi-log paper. The thin, $2 \times 0.062 \times 0.062$-in. samples are enclosed in stainless steel containers filled with helium for good heat transfer.

Small cubes 0.375 in. on an edge were used as samples for determina tion of hardness and microstructural changes accompanying transformation. The specimens were transformed in helium-filled containers by quenching from the gamma-annealing temperature directly into a salt bath held at a preselected temperature. After isothermal transformation the container was water-quenched. The hardness change with time at various temperatures is shown in Fig. 5. The data used for hardness portion of the TTT curves (Fig. 4) are based on the time to attain one-half of the fully aged hardness.

Microstructures of the alloy transformed at 550 and $600^{\circ} \mathrm{C}$ show a pearlitic type of structure. The alpha platelets nucleate at grain boundaries, and they advance into the grain interior as the gamma phase transforms. The plates appear coarser at the higher temperature. The morphology (i。e., the planes on which the growth occurs) has not been determined. Microstructures showing decomposition of the gamma phase to the pearlite structure at $600^{\circ} \mathrm{C}$ after $1,2.5$, and 8 hours are reproduced in Figs. 6, 7, and 8 , respectively。

Figures 9, 10, and 11 show the aging effect of $0.25,1$, and 8 hours, respectively, at $450^{\circ} \mathrm{C}$. Between 450 and $500^{\circ} \mathrm{C}$ the transformed material is much finer than at $600^{\circ} \mathrm{C}$ and is distributed throughout the grains as a veined 


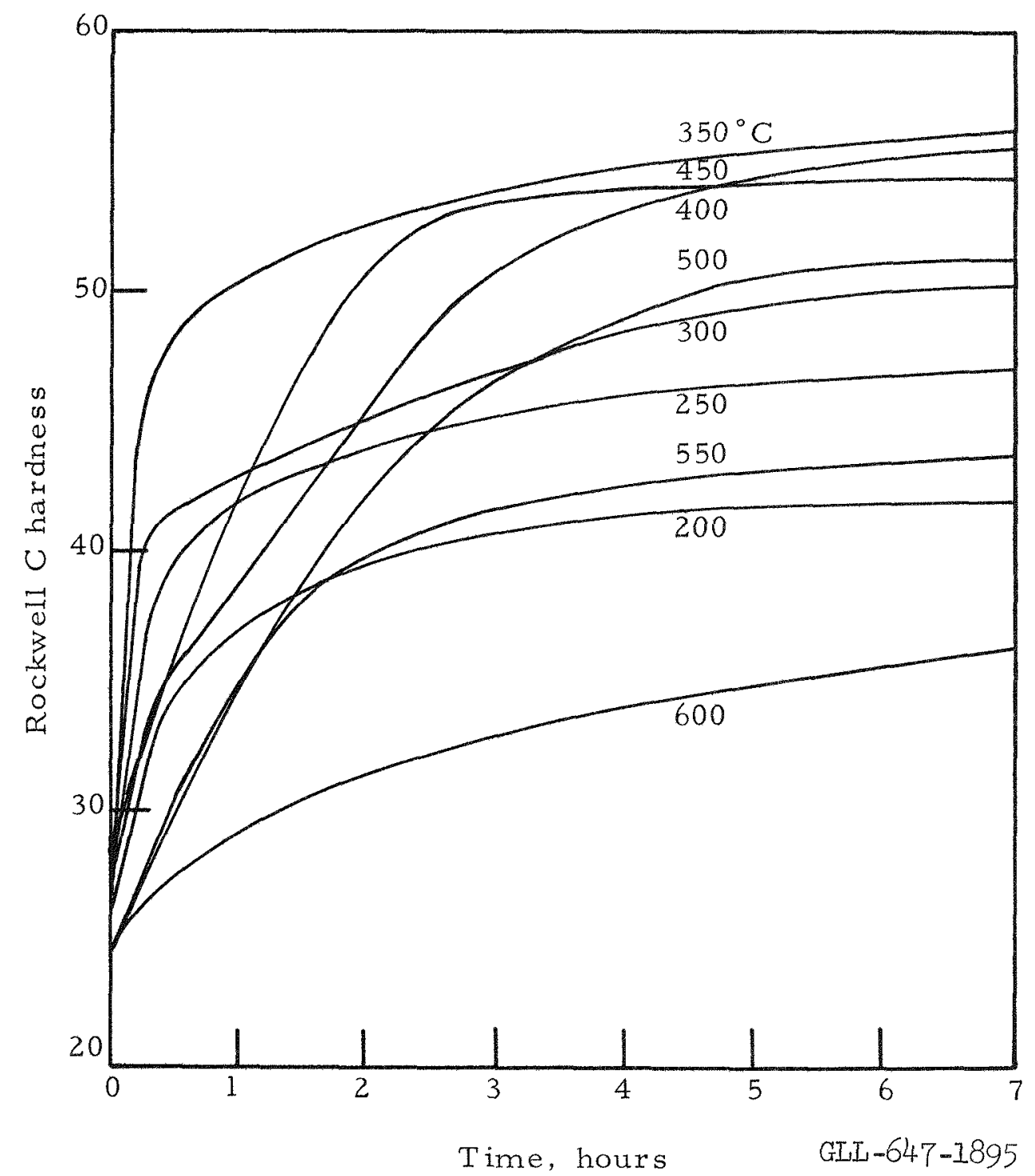

Fig. 5. Age hardening of $\mathrm{U}-7.5 \mathrm{w} / \mathrm{O} \mathrm{Nb}-2.5 \mathrm{w} / \mathrm{o} \mathrm{Zr}$. 
Isothermal Transformation of Gamma

$\mathrm{U}-7.5 \mathrm{w} / \mathrm{O} \mathrm{Nb}-2.5 \mathrm{w} / \mathrm{O} \mathrm{Zr}$ at $600^{\circ} \mathrm{C}$

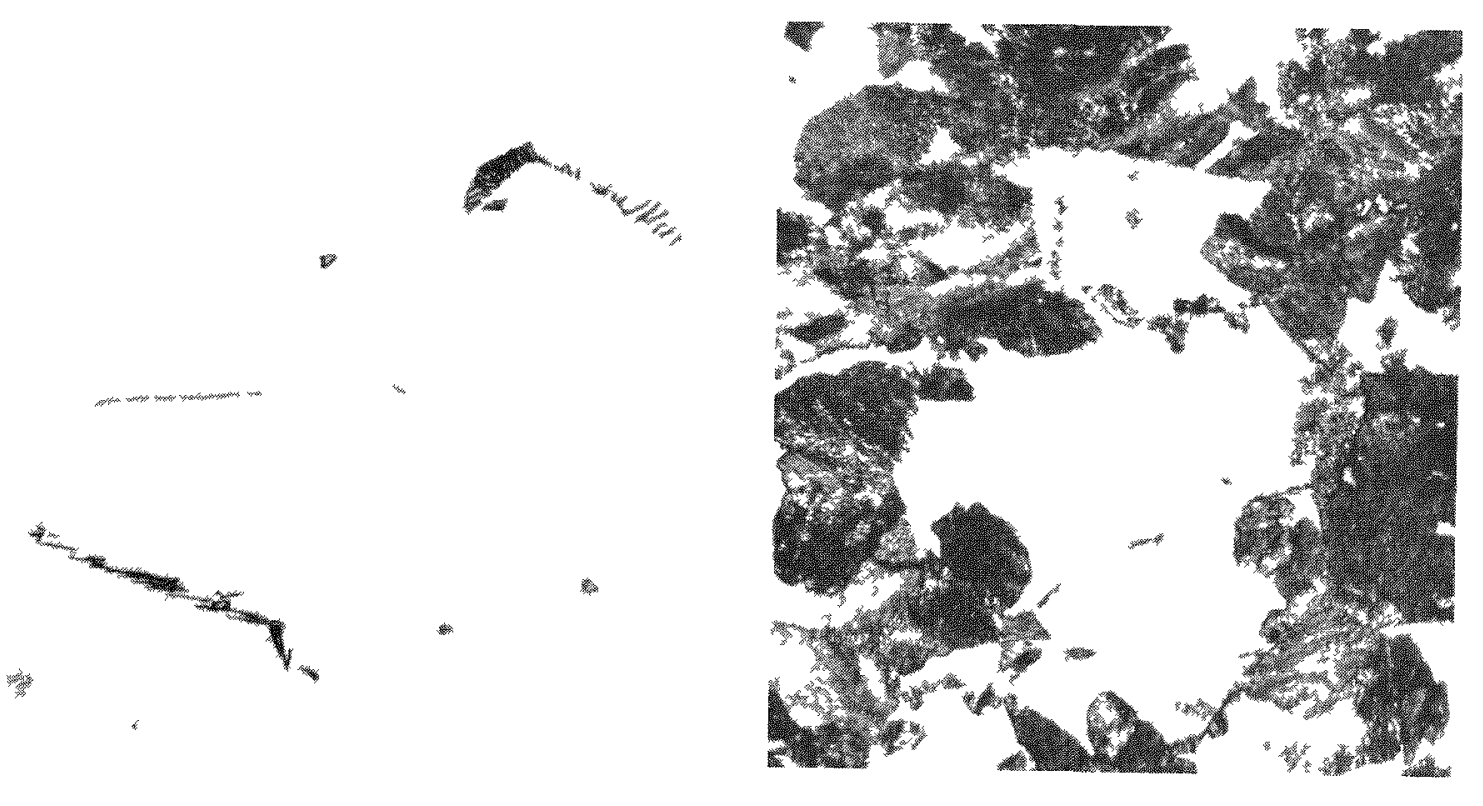

GLB $\quad 647 \quad 4240$

GLB $647 \quad 4249$

Fig. 6. 1 hour $(400 x)$

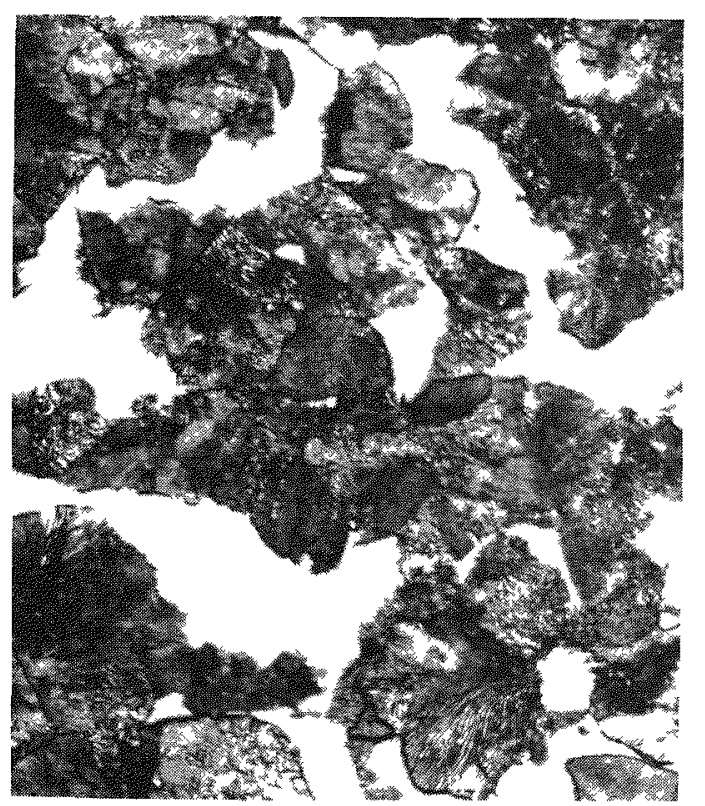

GLB 6474242

Fig. 8 a. 8 hours $(400 \times)$.
Fig. 72.5 hours $(400 x)$

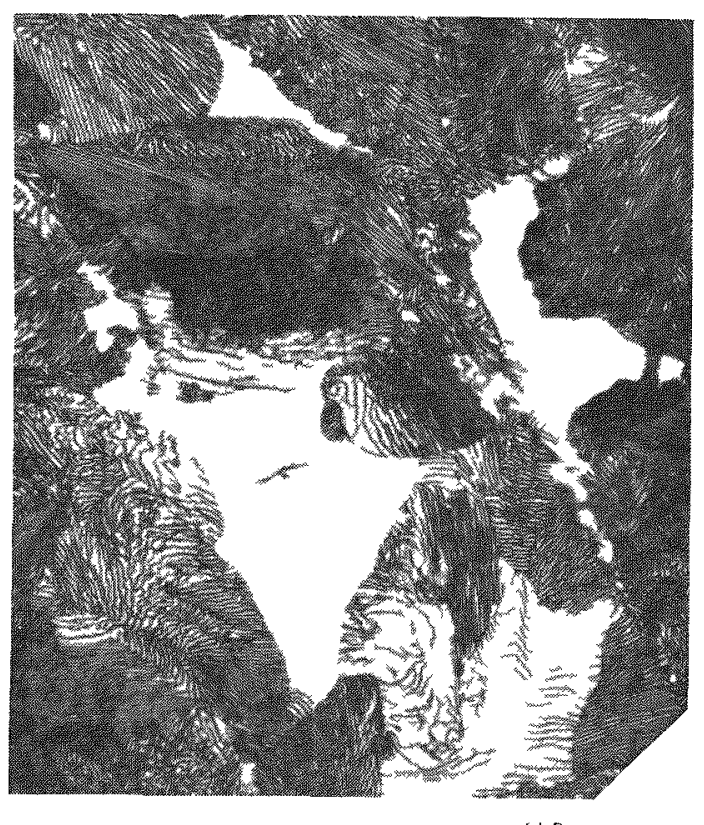

GLP

F1g. 8 b. 8 hours 1 
Isothermal Transformation of Gamma U-7.5 w/o $\mathrm{Nb}-2.5 \mathrm{w} / \mathrm{o} \mathrm{Zr}$ at $450^{\circ} \mathrm{C}$ (400x, Polarized Light)

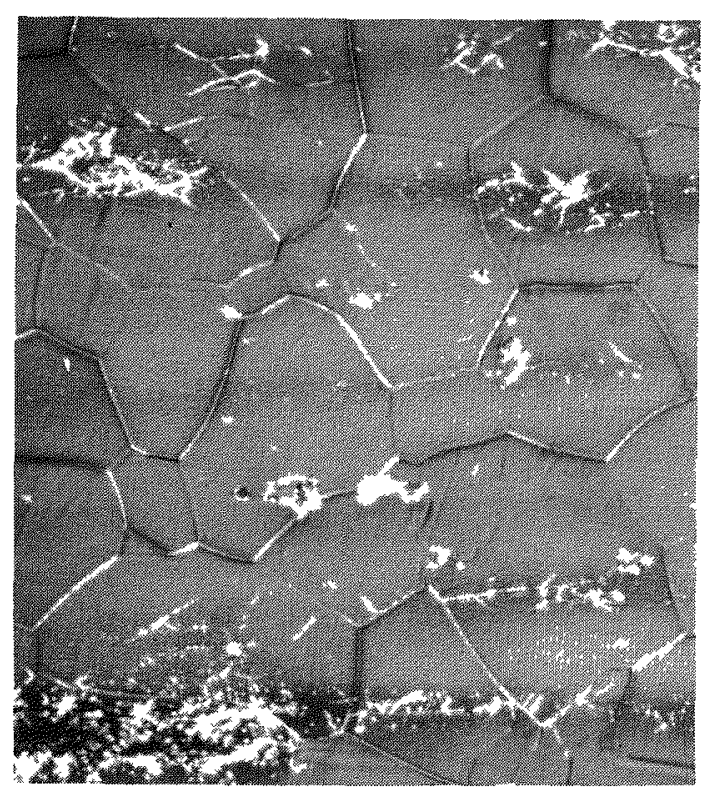

$\mathrm{GLB} \cdot 64 / \cdot 4244$

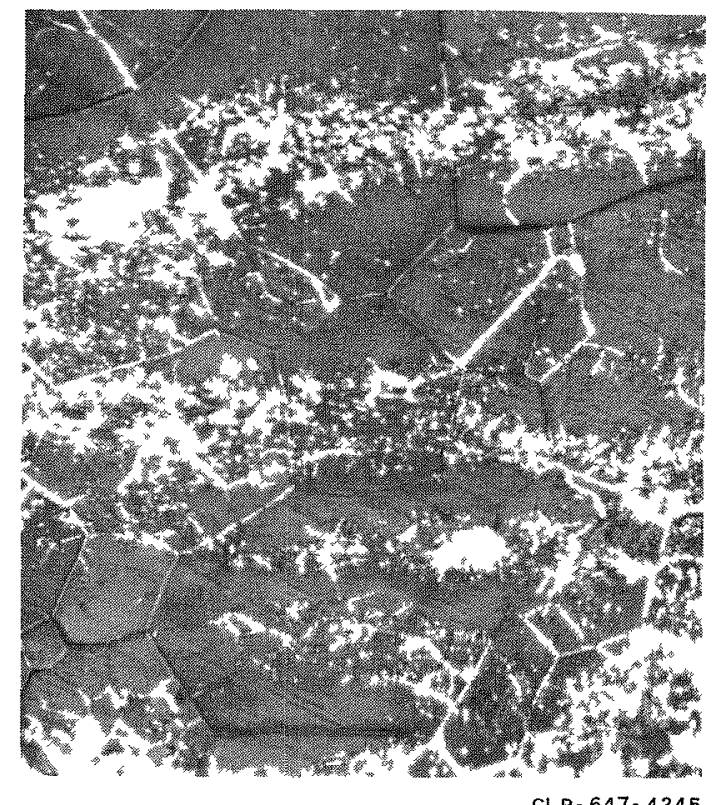

Fig. 10. 1 hour.

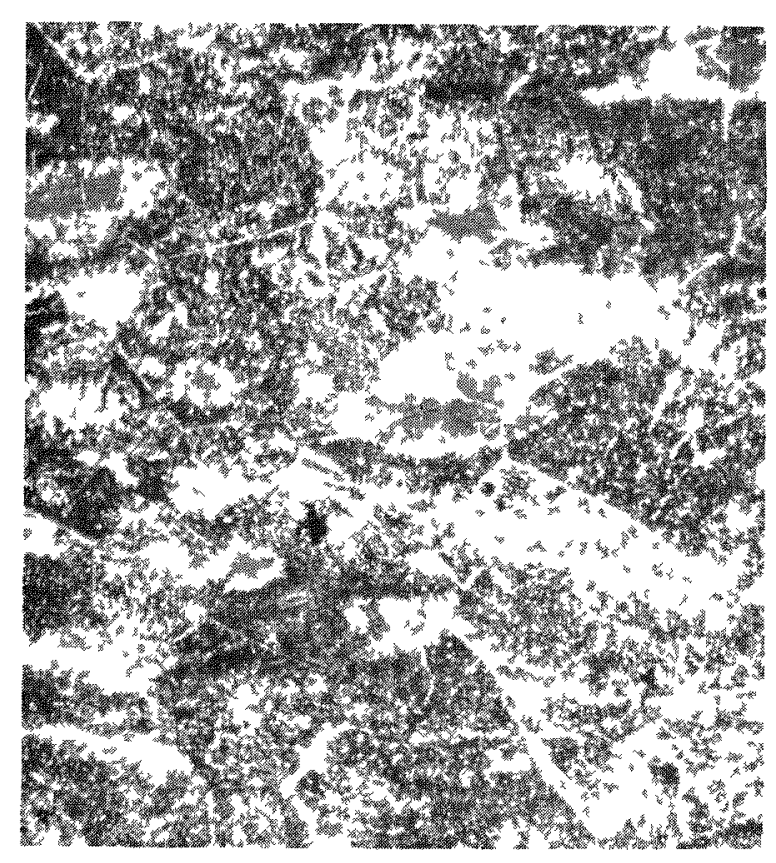

GLB $647 \cdot 4246$

Fig. 11. 8 hours. 
or salt-and-pepper type of nucleation product. Polarized light is used to bring this out more vividly.

At the temperatures below $450^{\circ} \mathrm{C}$ where the hardening effect is both rapid and intensive, the microstructures show a martensitic type of strained structure but no discrete phase of precipitate. Figure 12, taken of the structure as transformed for 1 hour at $350^{\circ} \mathrm{C}$, and Fig. 13, of the structure transformed for $2-1 / 2$ hours at $400^{\circ} \mathrm{C}$, show this type of pattern. Extensive line broadening in the $\mathrm{x}$-ray diffraction patterns lends evidence to support the existence of a highly stressed internal structure.

\section{PHYSICAL PROPERTIES}

Some of the physical properties as determined for the alloy are as follow :

1. Density at room temperature: cast, $16.4 \mathrm{~g} / \mathrm{cc}$; wrought, $16.6 \mathrm{~g} / \mathrm{cc}$.

2. Coefficient of linear expansion: see Table III.

3. Crystallography (as gamma-quenched): gamma phase, bodycentered cubic.

4. Electrical resistivity: gamma-quenched from $850^{\circ} \mathrm{C}, 70 \mu \mathrm{ohm}-\mathrm{cm}$; transformed 8 hours $600^{\circ} \mathrm{C}, 53 \mu \mathrm{ohm}-\mathrm{cm}$.

5. Specific heat at $23^{\circ} \mathrm{C}: 0.04 \mathrm{cal} / \mathrm{g}-{ }^{\circ} \mathrm{C}$.

\section{MECHANICAL PROPERTIES}

The yield strength, ultimate tensile strength, and ductility in tension, as well as the hardness and the toughness of the alloy, vary considerably depending upon the heat treatment given the alloy.

Table IV is a summary of the tensile properties for many heat treatments of the alloy. There is very little effect on the se properties due to different strain rates and environment in testing. The material with the highest strength and lowest ductility is the slowly cooled, gamma-annealed alloy and the gamma-quenched alloy aged at 350 to $450^{\circ} \mathrm{C}$. In the gammaquenched condition the metal is the softest and most ductile.

Figure 5 shows the response to hardening of the gamma-quenched alloy with different heat treatments.

Table V, which gives tensile data obtained on the alloy above and be room temperature, indicates no definite transition temperature from -? to $150^{\circ} \mathrm{C}$. Slight strongthoning occurs at the lower tempcraturc but d, remains the same. 
Isothermal Transformation of Gamma U-7.5 w/o Nb-2.5 w/o Zr (400X, Polarized Light)

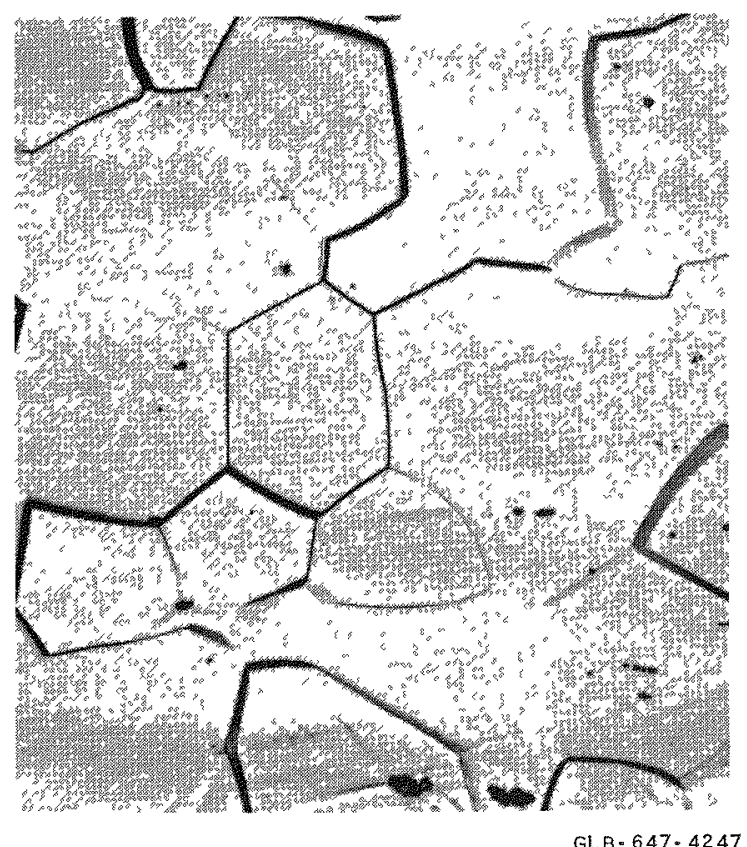

Fig. 12. 1 hour at $350^{\circ} \mathrm{C}$.

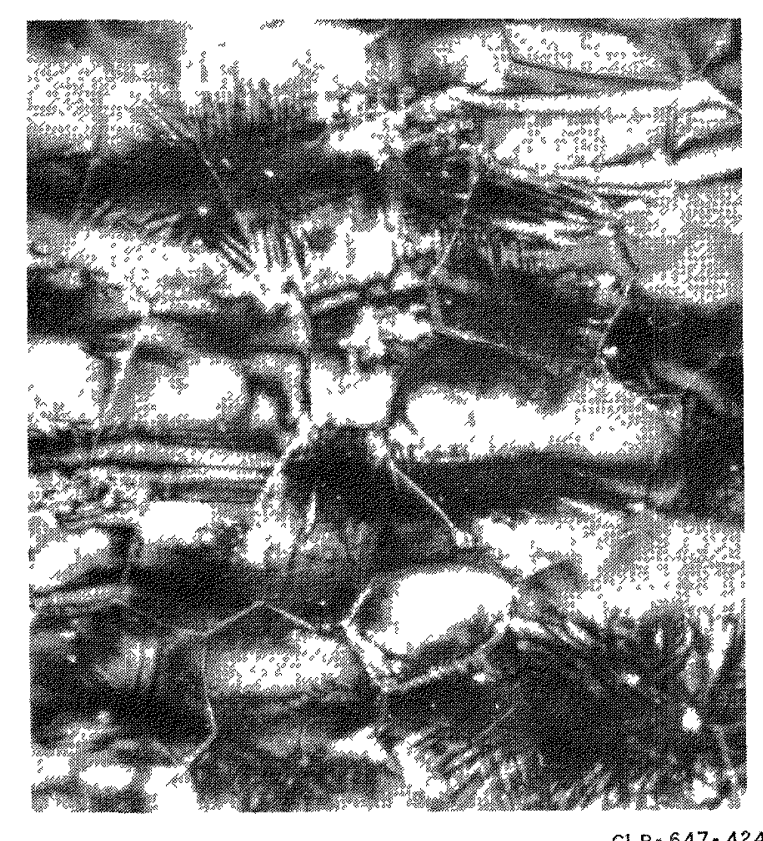

GLB $647 \cdot 4248$

Fig. 13. 2.5 hours at $400^{\circ} \mathrm{C}$. 
Table IV. Room-temperature tensile properties of $\mathrm{U}-7.5 \mathrm{w} / \mathrm{o} \mathrm{Nb}-2.5 \mathrm{w} / \mathrm{O} \mathrm{Zr}$ alloy.

\begin{tabular}{|c|c|c|c|c|c|c|}
\hline $\begin{array}{c}\text { Testing } \\
\text { environment }\end{array}$ & Conditioning of sample & $\begin{array}{l}\text { Strain } \\
\text { rate } \\
\text { (in./in.-min) }\end{array}$ & $\begin{array}{c}\text { Yield strength, } \\
0.2 \% \text { off set } \\
\text { (psi) }\end{array}$ & $\underset{\text { Upsi) }}{\text { U. T.S. }}$ & $\begin{array}{l}\% \text { elong. } \\
\text { in } 2 \text { in. }\end{array}$ & $\begin{array}{r}\% \\
\mathrm{RA}\end{array}$ \\
\hline Air, $R$ & $900^{\circ} \mathrm{C} / 30 \mathrm{~min} / \mathrm{vac} \cdot / \mathrm{W} \mathrm{Q}$ & 0.05 & 68,300 & 152,300 & 12.3 & 46 \\
\hline Air, F & $840^{\circ} \mathrm{C} / \mathrm{salt} \mathrm{bath} / 30 \mathrm{~min} / \mathrm{AC}$ & 0.05 & 87,000 & 182,300 & 10.5 & 24 \\
\hline Air, $R$ & $800^{\circ} \mathrm{C} / 1$ hour/vac./WQ & 0.05 & 100,300 & 128,300 & 12.5 & 21 \\
\hline Air, $R$ & $800^{\circ} \mathrm{C} / 1$ hour $/$ vac. $/ W Q$ & 0.05 & 108,300 & 130,300 & 12.0 & 21 \\
\hline *Air, F & 11 & 0.05 & 95,000 & 130,200 & 12.0 & 34 \\
\hline Air, $R$ & $950^{\circ} \mathrm{C} / 1$ hour/argon/AC & 0.05 & 131,400 & 190,800 & 5.2 & - \\
\hline Vac., $\mathrm{R}$ & 11 & 0.05 & 134,300 & 191,300 & 5.2 & - \\
\hline Air, R & $" 1$ & 0.0005 & 113,500 & 185,500 & 6.5 & - \\
\hline Air, R & 11 & 0.05 & 143,800 & 176,200 & 6.9 & - \\
\hline Air, $R$ & $800^{\circ} \mathrm{C} / 1$ hour/vac. $/ \mathrm{WQ}+8$ hours $/ 600^{\circ} \mathrm{C}$ & 0.05 & 129,400 & 186,200 & 8.4 & - \\
\hline Air, $R$ & $" 11$ & 0.05 & 138,400 & 191,500 & 7.8 & - \\
\hline Air, $R$ & $900^{\circ} \mathrm{C} / 1$ hour/vac. $/ \mathrm{WQ}+1$ hour $/ 600^{\circ} \mathrm{C}$ & 0.05 & 66,500 & 163,600 & 13.0 & 41 \\
\hline Air, $R$ & $900^{\circ} \mathrm{C} / 1$ hour/vac. $/ \mathrm{W} Q+1$ hour $/ 500^{\circ} \mathrm{C}$ & 0.05 & 77,000 & 177,000 & 9.5 & 33 \\
\hline Air, $R$ & $900^{\circ} \mathrm{C} / 1$ hour $/$ vac. $/ \mathrm{WQ}+1$ hour $/ 400^{\circ} \mathrm{C}$ & 0.05 & 210,000 & 219,000 & 1.0 & 1.3 \\
\hline Air, R & $900^{\circ} \mathrm{C} / 1$ hour $/ \mathrm{vac} . / \mathrm{WQ}+1$ hour $/ 350^{\circ} \mathrm{C}$ & 0.05 & 220,000 & 225,000 & 1.0 & 0.5 \\
\hline
\end{tabular}


Table IV. Room-temperature tensile properties of $\mathrm{U}-7.5 \mathrm{w} / \mathrm{o} \mathrm{Nb}-2.5 \mathrm{w} / \mathrm{o} \mathrm{Zr}$ alloy. (Continued)

\begin{tabular}{|c|c|c|c|c|c|c|}
\hline $\begin{array}{l}\text { Testing } \\
\text { environment }\end{array}$ & Conditioning of sample & $\begin{array}{c}\text { Strain } \\
\text { rate } \\
\text { (in./in. }-\mathrm{min} \text { ) }\end{array}$ & $\begin{array}{c}\text { Yield strength, } \\
0.2 \% \text { offset } \\
\text { (psi) }\end{array}$ & $\begin{array}{c}\text { U. T. S. } \\
\text { (psi) }\end{array}$ & $\begin{array}{l}\% \text { elong. } \\
\text { in } 2 \text { in. }\end{array}$ & $\begin{array}{r}\% \\
\mathrm{RA}\end{array}$ \\
\hline Air, F & $800^{\circ} \mathrm{C} / 1$ hour $/$ vac. $/ \mathrm{WQ}+\mathrm{I}$ hour $/ 400^{\circ} \mathrm{C}$ & 0.05 & 244,000 & 251,000 & 0.5 & - \\
\hline Air, $F$ & 11 & 0.05 & 230,000 & 251,000 & 1.0 & 1.3 \\
\hline Air, $F$ & $350^{\circ} \mathrm{C}$ & 0.05 & 209,000 & 230,000 & 6 & 17 \\
\hline Air, $F$ & 4 hours $/ 350^{\circ} \mathrm{C}$ & 0.05 & 260,000 & 270,000 & 2 & 2 \\
\hline
\end{tabular}

* Stressed over 200 hours at $90 \%$ Y. S. before testing.

$\mathrm{R}=$ round-shoulder type tensile bars.

$F=$ flat-grip type tensile bars.

$W Q=$ water-quenched.

$\mathrm{AC}=$ air-cooled. 
Table V. Effect of temperature of testing on tensile properties of $90 \mathrm{U}-7.5$ $\mathrm{w} / \mathrm{O} \mathrm{Nb}-2.5 \mathrm{w} / \mathrm{O} \mathrm{Zr}$ alloy, vacuum-annealed at $900^{\circ} \mathrm{C}$ and water-quenched.

\begin{tabular}{llcccc}
\hline $\begin{array}{l}\text { Tempera- } \\
\text { ture of test } \\
\left({ }^{\circ} \mathrm{C}\right)\end{array}$ & Condition of sample & $\begin{array}{c}\text { Yield strength, } \\
\text { 0.1\% offset } \\
\text { (psi) }\end{array}$ & $\begin{array}{c}\text { U. T. S. \% elong. } \\
\text { (psi) }\end{array}$ & $\begin{array}{c}\% \\
\text { in 2 in. }\end{array}$ & RA \\
\hline 150 & $900^{\circ} \mathrm{C} / \mathrm{vac} / / \frac{1}{2}$ hour/WQ & 74,000 & 132,000 & 12.5 & 45 \\
100 & $900^{\circ} \mathrm{C} / \mathrm{vac} / \frac{1}{2}$ hour/WQ & 68,200 & 137,000 & 12.0 & 45 \\
25 & $900^{\circ} \mathrm{C} / \mathrm{vac} / \frac{1}{2}$ hour/WQ & 68,300 & 150,000 & 12.3 & 46 \\
0 & $900^{\circ} \mathrm{C} / \mathrm{vac} / \frac{1}{2}$ hour $/ \mathrm{WQ}$ & 64,000 & 159,000 & 13.0 & 46 \\
-30 & $900^{\circ} \mathrm{C} / \mathrm{vac} / \frac{1}{2}$ hour/WQ & 65,000 & 166,000 & 15.3 & 47.5 \\
\hline
\end{tabular}

$W Q=$ water - quenched.

The standard, room-temperature Charpy-impact-test data given in Table VI correlate well with the tensile results. The toughness of the gammaquenched alloy is good. Aging of the alloy to give high tensile strength adversely affects the impact strength and ductility. Photomicrographs (Figs.14 and 15) show the great difference in fracture pattern between gamma-quenched and aged materials. Slowly cooled material has an impact strength between these two; the structure at the fracture of gamma-annealed and air-cooled plate is shown in Fig. 16. Quenching gamma-annealed alloy directly to the transformation temperature instead of first quenching to room temperature produces better toughness for the same strength of alloy. Also, lower temperature gamma-anneals give better Charpy impact strength than high temperature anneals.

Table VII indicates that, as in the case of tensile data, there is no change in toughness from $100^{\circ} \mathrm{C}$ down to $-40^{\circ} \mathrm{C}$ for the $\mathrm{U}-7.5 \mathrm{w} / \mathrm{o} \mathrm{Nb}-2.5 \mathrm{w} / \mathrm{O}$ Zr gamma-annealed alloy。

The tensile properties of the alloy at temperatures up to $1000^{\circ} \mathrm{C}$ are quite good. Some tensile data obtained on thin strip specimens heated by electric current in a Marquardt tensile tester are summarized in Table VIII and given in graph form in Fig. 17. The tests conducted at the slower strain rate of $0.03 \mathrm{in./in.-min} \mathrm{gave} \mathrm{questionable} \mathrm{yield-load} \mathrm{results,} \mathrm{particularly}$ above $650^{\circ} \mathrm{C}$. The tests at the higher strain rate of $6 \mathrm{in}$./in.-min gave much more consistent data for both yield loads and elongation.

The counteraction of the natural annealing effect by the transformation aging effect as the temperature of the test rises is apparent at temperatures 
Table VI. Effect of heat treatment on room-temperature $V$-notch Charpy values of $\mathrm{U}-7.5 \mathrm{w} / \mathrm{O} \mathrm{Nb}-2.5 \mathrm{w} / \mathrm{o} \mathrm{Zr}$ alloy.

\begin{tabular}{|c|c|c|c|}
\hline Heat treatment & $\begin{array}{c}\text { Cha rpy } \\
(\mathrm{ft}-1 \mathrm{~b})\end{array}$ & $\begin{array}{c}\text { Rockwell C } \\
\text { hardness }\end{array}$ & $\begin{array}{c}X \text {-ray } \\
\text { structure }\end{array}$ \\
\hline $950^{\circ} \mathrm{C} / 1$ hour/argon + argon $Q$ & 5.4 & 41 & Y \\
\hline $900^{\circ} \mathrm{C} / 1$ hour/vac + water $Q$ & 16.3 & 23 & $\gamma$ \\
\hline $840^{\circ} \mathrm{C} / 1$ hour $/$ salt + water $Q$ & 20.8 & 17 & $\gamma$ \\
\hline $800^{\circ} \mathrm{C} / 1$ hour $/$ salt + water $Q$ & 15.6 & 22 & $\gamma$ \\
\hline $800^{\circ} \mathrm{C} / 1$ hour/vac. + water $\mathrm{Q}$ & 20.7 & 23 & Y \\
\hline $800^{\circ} \mathrm{C} / 1$ hour/vac + tube $\mathrm{Q}$ & 9.5 & 43 & $\gamma$ \\
\hline $800^{\circ} \mathrm{C} / 1$ hour/vac. + oil $\mathrm{Q}$ & 15.3 & 22 & $\gamma$ \\
\hline $800^{\circ} \mathrm{C} / 3$ hours $/$ salt + water $Q$ & 16.8 & 18 & $\gamma$ \\
\hline $750^{\circ} \mathrm{C} / 3$ hours $/$ salt + water $Q$ & 9.6 & 18.5 & $\gamma$ \\
\hline $950^{\circ} \mathrm{C} / 1$ hour/argon $\mathrm{Q}+350^{\circ} \mathrm{C} / 1$ hour & 4.2 & 46 & $a+\gamma^{\prime}$ \\
\hline $950^{\circ} \mathrm{C} / 1$ hour/argon $\mathrm{Q}+350^{\circ} \mathrm{C} / 8$ hours & 3.7 & 47 & $a+\gamma^{\prime}$ \\
\hline $950^{\circ} \mathrm{C} / 1$ hour/argon $Q+400^{\circ} \mathrm{C} / 1$ hour & 3.6 & 52 & $a+\gamma^{\prime}$ \\
\hline $950^{\circ} \mathrm{C} / 1$ hour/argon $\mathrm{Q}+600^{\circ} \mathrm{C} / 8$ hours & 3.5 & 48.5 & $a+\gamma^{\prime}$ \\
\hline $800^{\circ} \mathrm{C} / 1$ hour/vac. $\mathrm{Q}+350^{\circ} \mathrm{C} / 1$ hour & 9.8 & 45 & $a+\gamma^{\prime}$ \\
\hline $800^{\circ} \mathrm{C} / 1$ hour $/$ vac. $\mathrm{Q}+400^{\circ} \mathrm{C} / \frac{1}{2}$ hour & 9.0 & 44 & $a+\gamma^{\prime}$ \\
\hline $800^{\circ} \mathrm{C} / 1$ hour/vac. $\mathrm{Q}+400^{\circ} \mathrm{C} / 1$ hour & 6.1 & 47.5 & $a+\gamma^{\prime}$ \\
\hline $800^{\circ} \mathrm{C} / 1$ hour $/$ vac. $\mathrm{Q}+400^{\circ} \mathrm{C} / 2$ hours & 3.7 & 52.0 & $a+\gamma^{\prime}$ \\
\hline $800^{\circ} \mathrm{C} / 1$ hour/vac. $\mathrm{Q}+600^{\circ} \mathrm{C} / 1$ hour & 9.6 & 33 & $a+\gamma^{\prime}$ \\
\hline $800^{\circ} \mathrm{C} / 1$ hour/vac. $\mathrm{Q}+600^{\circ} \mathrm{C} / 8$ hours & 4.8 & 43 & $a+\gamma^{\prime}$ \\
\hline
\end{tabular}


Fractures of V-Notch Charpy Bars of U-7.5 w/o Nb-2.5 w/o Zr (400X)

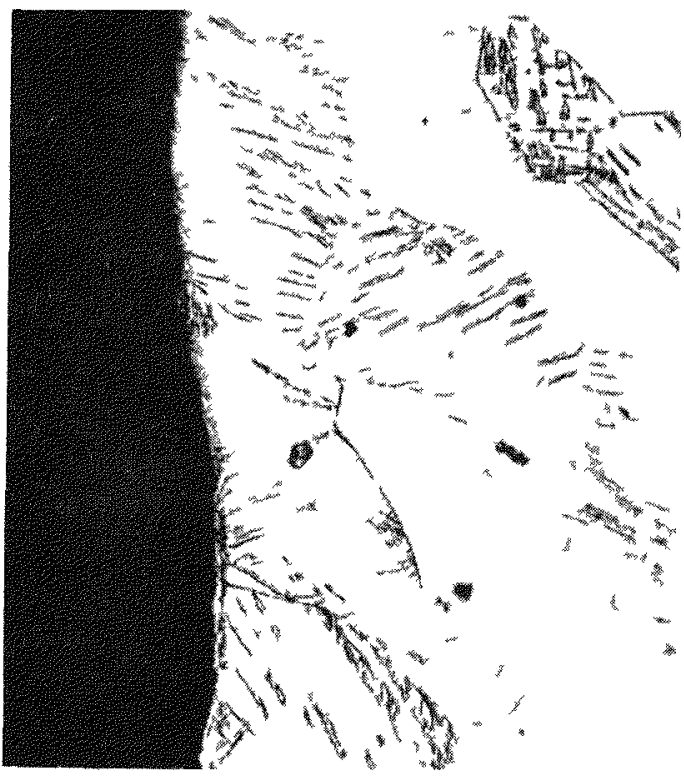

GLB $B \cdot 647 \cdot 4249$
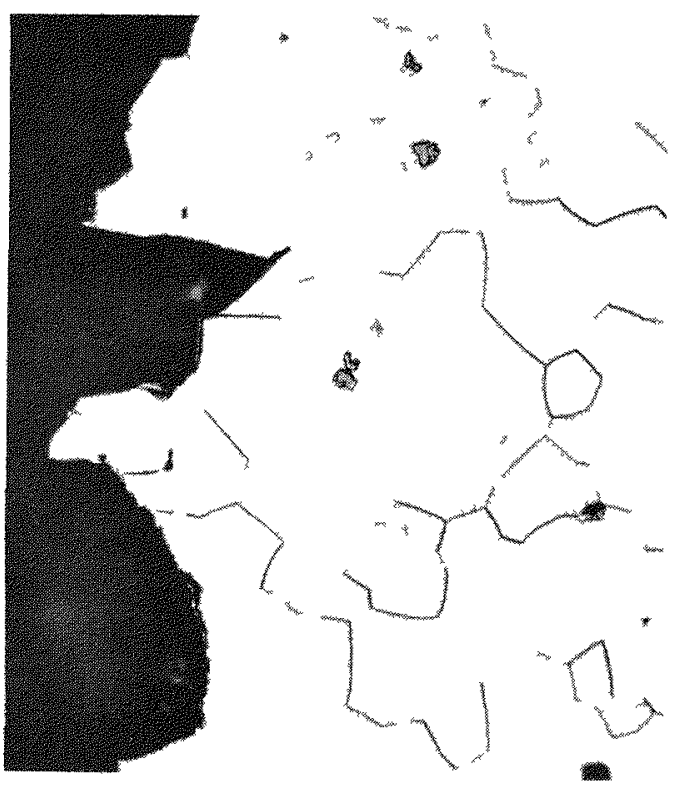

GLB $-647 \cdot 4250$

Fig. 14. As gamma-quenched. Fig. 15. As aged 1 hour at $400^{\circ} \mathrm{C}$.

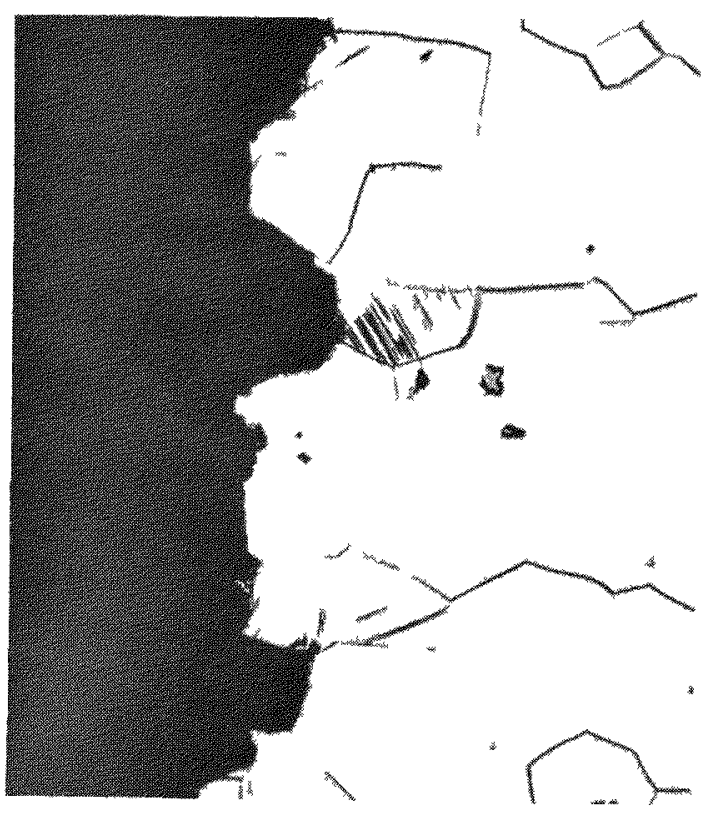

GLB $\cdot 647 \cdot 425$ ?

Fig. 16. As gamma-annealed, air-cooled. 
Table VII. V-notch Charpy impact values of gammaannealed $\mathrm{U}-7.5 \mathrm{w} / \mathrm{O} \mathrm{Nb}-2.5 \mathrm{w} / \mathrm{O} \mathrm{Zr}$ alloy at various temperatures.

\begin{tabular}{cc}
\hline Temperature $\left({ }^{\circ} \mathrm{C}\right)$ & Charpy $(\mathrm{ft}-1 \mathrm{~b})$ \\
\hline 100 & 11.0 \\
25 & 12.5 \\
0 & 10.8 \\
-40 & 10.3
\end{tabular}

Table VIII. Elevated-temperature tensile tests of $\mathrm{U}-7.5 \mathrm{w} / \mathrm{O} \mathrm{Nb}-2.5 \mathrm{w} / \mathrm{O}$ Zralloy.

\begin{tabular}{|c|c|c|c|c|c|}
\hline $\begin{array}{c}\text { Temperature } \\
\left({ }^{\circ} \mathrm{C}\right) \\
\end{array}$ & $\begin{array}{c}\text { Strain rate } \\
\text { (in./in. }- \text { min) }\end{array}$ & $\begin{array}{c}\text { Yield strength } \\
\text { (psi) }\end{array}$ & $\begin{array}{c}\text { U. T.S. } \\
\text { (psi) }\end{array}$ & $\begin{array}{l}\% \text { elong. } \\
\text { in } 1 \text { in. }\end{array}$ & $\begin{array}{r}\text { RA } \\
(\%) \\
\end{array}$ \\
\hline $\mathrm{R} \cdot \mathrm{T}$ & 0.03 & 95,700 & 109,400 & 32 & 51 \\
\hline 150 & $" 1$ & 71,400 & 91,400 & 24 & 46 \\
\hline 250 & 11 & 60,200 & 92,700 & 15 & 41 \\
\hline 350 & $" 1$ & 56,800 & 96,300 & $*$ & 28 \\
\hline 450 & $" 1$ & 46,700 & 85,500 & 7 & 14 \\
\hline 550 & 11 & 25,700 & 33,300 & 19 & 60 \\
\hline 650 & 11 & 17,500 & 17,500 & 25 & 47 \\
\hline 750 & 11 & $* *$ & 12,300 & 59 & 38 \\
\hline 850 & $" 1$ & $\%$ & 6,700 & 60 & 36 \\
\hline 950 & 11 & $* \%$ & 4,300 & 49 & 63 \\
\hline R. T. & 6.0 & 101,000 & 111,000 & $*$ & 42 \\
\hline 150 & 11 & 71,200 & 90,300 & 20 & 39 \\
\hline 250 & 11 & 69,400 & 84,800 & 14 & 38 \\
\hline 350 & $" 1$ & 71,400 & 78,300 & 10 & 36 \\
\hline 450 & $" 1$ & 53,800 & 59,600 & 8 & 44 \\
\hline 550 & $" 1$ & 37,600 & 41,000 & 12 & 52 \\
\hline 650 & 11 & 24,100 & 26,000 & 19 & 59 \\
\hline 750 & 11 & 18,800 & 18,850 & 29 & 60 \\
\hline 850 & $" 1$ & 14,100 & 15,000 & 40 & 74 \\
\hline 950 & $" 1$ & $* * *$ & 10,300 & 60 & 85 \\
\hline
\end{tabular}

* Broke outside gauge length.

** Yield load is questionable. 


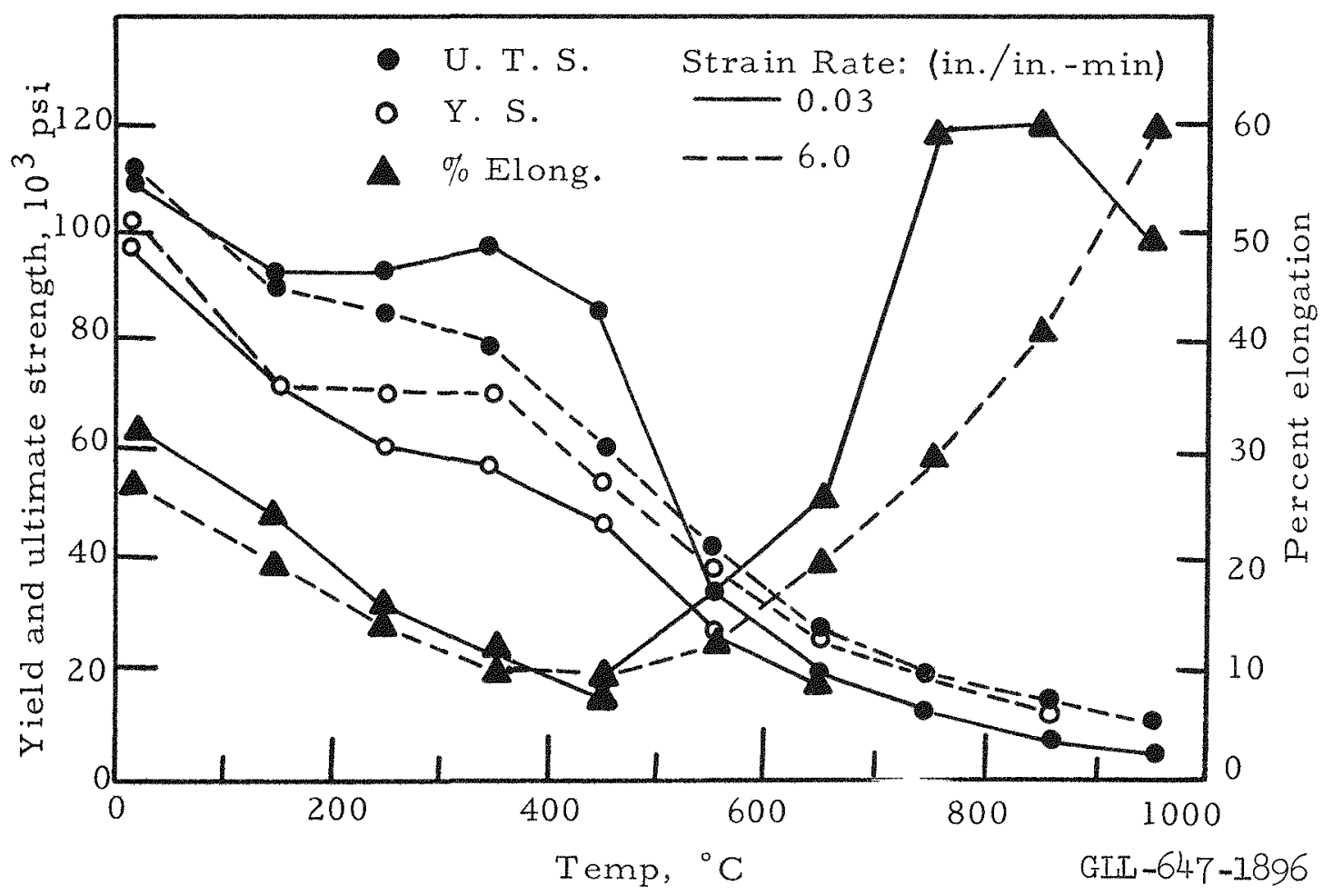

Fig. 17. Tensile properties of $\mathrm{U}-7.5 \mathrm{w} / \mathrm{O} \mathrm{Nb}-2.5 \mathrm{w} / \mathrm{O} \mathrm{Zr}$ at elevated temperatures. 
in the range of $500-600^{\circ} \mathrm{C}$. As the temperature becomes elevated to the point where nucleation processes predominate, the alloy anneals and softens rapidly.

\section{FABRICATION PROPERTIES}

For the best primary or secondary working properties the alloy must be in the gamma-phase condition above $700^{\circ} \mathrm{C}$. For forging and breakdown rolling a starting temperature of $950^{\circ} \mathrm{C}$ is recommended. For hot-forming thin sections (finish-rolling), and to keep a fine grain size, the fabrication range is restricted between 800 and $700^{\circ} \mathrm{C}$. Warm-rolling below $650^{\circ} \mathrm{C}$ is unsuccessful due to duplex structure formation caused by transformation reactions. Such material is "hot short" and fractures in the grain boundaries with little or no reduction.

Homogeneous material, gamma-annealed above $750^{\circ} \mathrm{C}$ and rapidly cooled, may be cold-worked at room temperature with reductions of $80 \%$ in thicknes between anneals. Figure 18 shows the low work-hardening characteristics of the gamma-annealed-and-quenched alloy.

The recrystallization temperature for the $50 \%$ cold-rolled alloy is between 600 and $650^{\circ} \mathrm{C}$, as indicated by the annealing curve of Fig. 19. Figure 20 shows that the cold-worked structure has not been removed by a 1 -hour anneal at $600^{\circ} \mathrm{C} ; \mathrm{Fig}, 21$ shows that after 1 hour at $650^{\circ} \mathrm{C}$ the structure has been completely recrystallized.

Heavy sections such as thick plates, when slowly cooled from the gammaphase temperature, age-harden before reaching room temperature. Coldrolling before fracture is limited to approximately $30 \%$ reduction in thickness with very little work-hardening. Transformation of the structure to pearlite at $600^{\circ} \mathrm{C}$ allows about the same degree of cold-rolling. Alloy transformed to maximum hardness at lower temperatures has no cold-reduction capability.

\section{WELDABILITY}

Parts made from the $\mathrm{U}-7.5 \mathrm{w} / \mathrm{O} \mathrm{Nb}-2.5 \mathrm{w} / \mathrm{O} \mathrm{Zr}$ alloy are as readily joined by TIG or electron beam fusion welding as parts made of unalloyed uranium. In the TIG process either argon or helium forms the protective atmosphere within the welding chamber. The electron beam process operates in a vacuum of at least $10^{-4}$ torr. The alloy becomes suddenly quite fluid and some skill is required when deep penetration is required. 


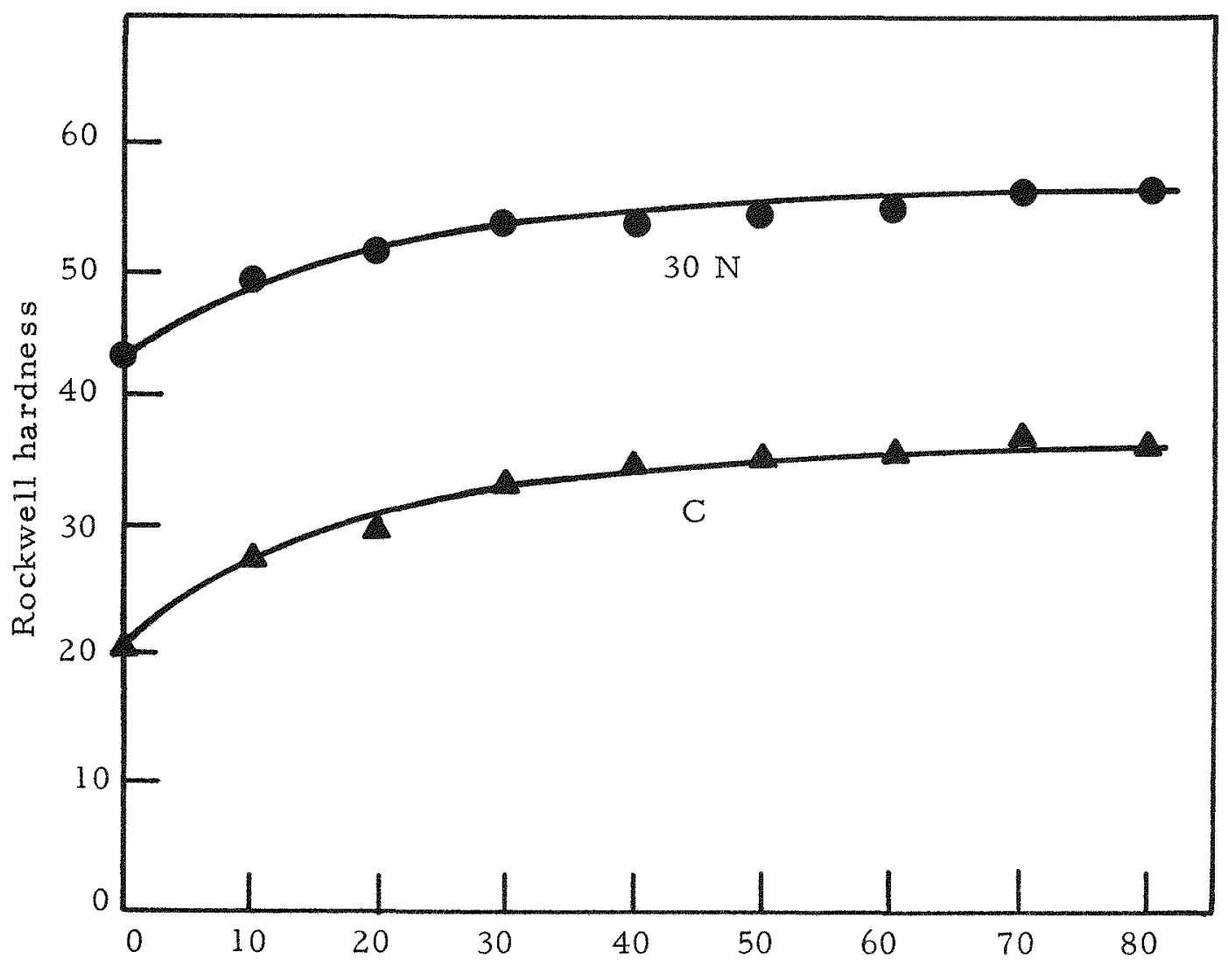

Percent reduction by cold rolling GLL-647-1897

Fig. 18. Hardness of U $-7.5 \mathrm{w} / \mathrm{O} \mathrm{Nb}-2.5 \mathrm{w} / \mathrm{O} \mathrm{Zr}$ as a function of percent reduction by cold rolling. 


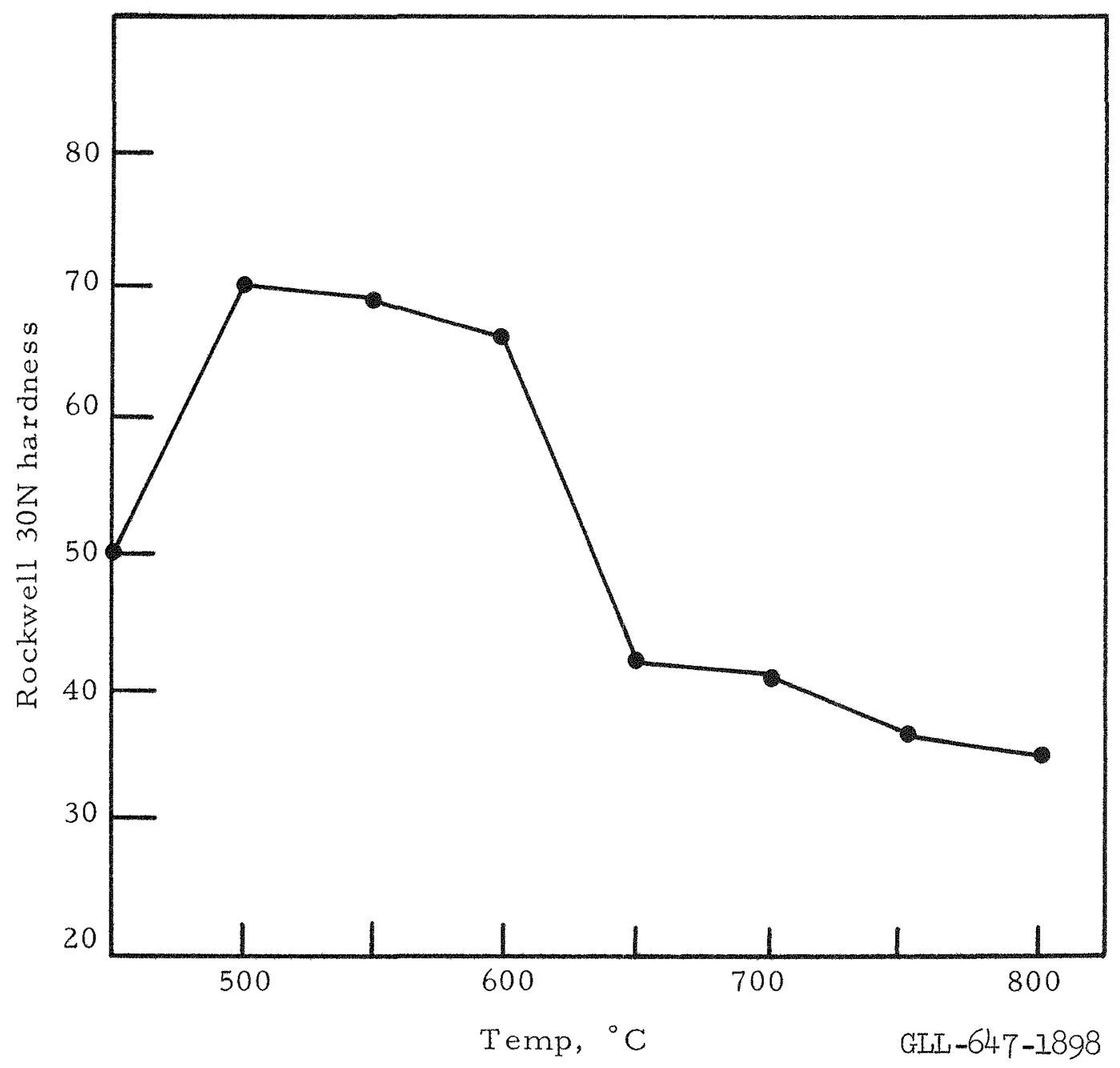

Fig. 19. Hardness of $\mathrm{U}-7.5 \mathrm{w} / \mathrm{O} \mathrm{Nb}-2.5 \mathrm{w} / \mathrm{O} \mathrm{Zr}$ as a function of annealing temperature. 
Recrystallization of $50 \%$ Cold-Rolled Gamma $\mathrm{U}-7.5 \mathrm{w} / \mathrm{O} \mathrm{Nb}-2.5 \mathrm{w} / \mathrm{O} \mathrm{Zr}(400 \times)$

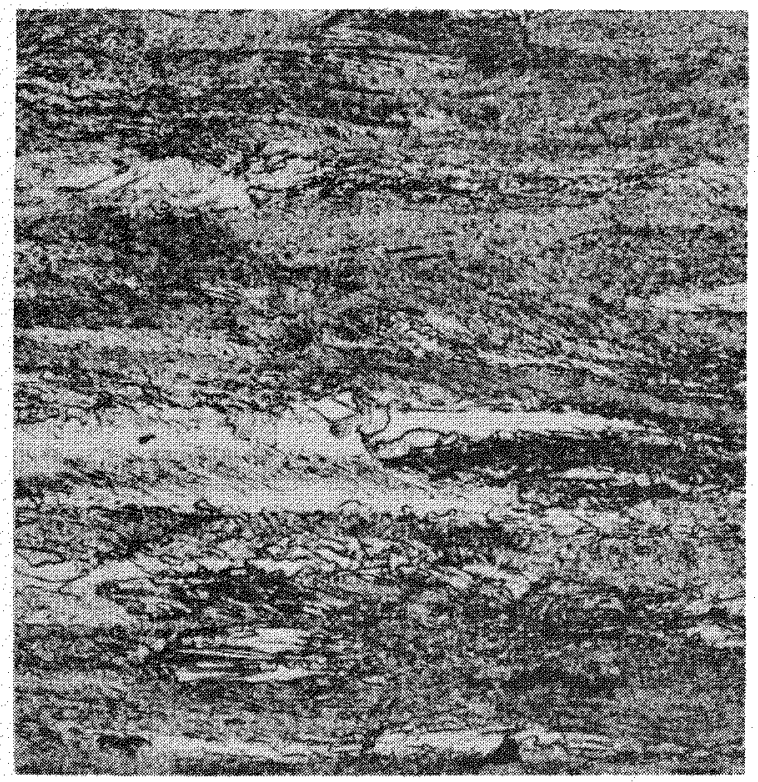

GL. B. $647 \cdot 4253$

Fig. 20. Annealed 1 hour at $600^{\circ} \mathrm{C}$.

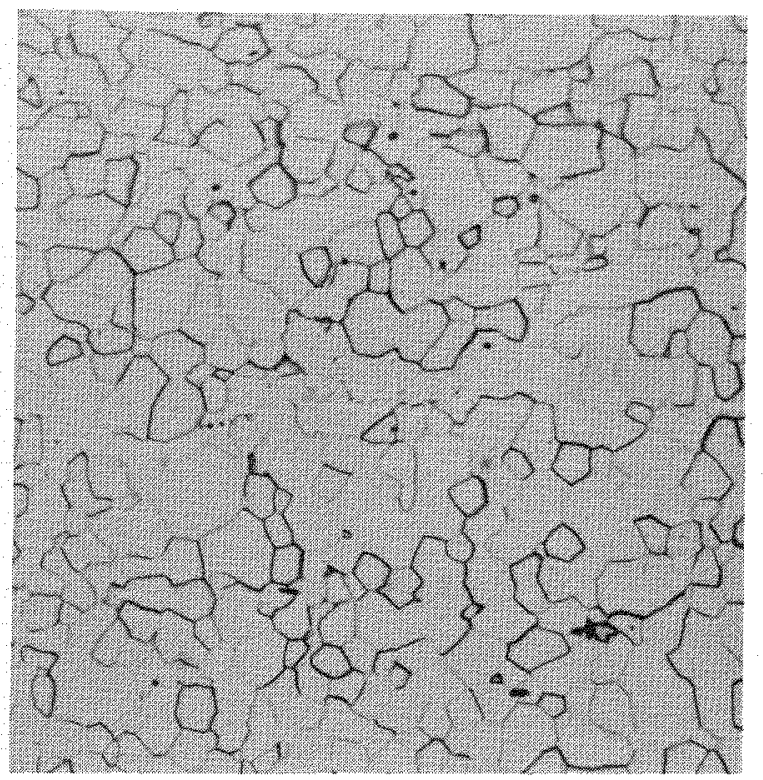

$\mathrm{GLB} \cdot 647 \cdot 4254$

Fig. 21. Annealed 1 hour at $650^{\circ} \mathrm{C}$. 
The cracking under residual stress which is common in the U-10 w/o Mo binary alloy does not occur in the $\mathrm{U}-7.5 \mathrm{w} / \mathrm{O} \mathrm{Nb}-2.5 \mathrm{w} / \mathrm{O} \mathrm{Zr}$ alloy welds.

Table IX shows that the gamma phase alloy in the as-welded condition possesses excellent mechanical properties. The strengthening of the weld which occurs as a result of some transformation on cooling to room temperature may be enhanced by post-heating at a low temperature.

\section{STRESS-CRACKING}

Static loading or stressing at low strain rates in environments containing oxygen ${ }^{4}$ have no detrimental effects upon the room-temperature tensile properties of the $\mathrm{U}-7.5 \mathrm{w} / \mathrm{O} \mathrm{Nb}-2.5 \mathrm{w} / \mathrm{O} \mathrm{Zr}$ alloy. Table $\mathrm{X}$ shows the properties after preloading 200 hours at 100,000 psi compared with results on samples that were not preloaded. The samples tested in air give the same results as those tested in vacuum. As would be expected, tests conducted at a strain rate of $0.0005 \mathrm{in.} / \mathrm{in}$ - min had a slightly lower yield stress and a small increase in ductility.

Table IX. Tensile properties of TIG-welded, gamma-annealed $\mathrm{U}-7.5 \mathrm{w} / \mathrm{o} \mathrm{Nb}-2.5 \mathrm{w} / \mathrm{o} \mathrm{Zr}$ alloy plates $(3 \times 4 \times 0.350 \mathrm{in}$.).

\begin{tabular}{lccc}
\hline Condition & $\begin{array}{c}\text { Yield strength, } \\
0.1 \% \text { offset } \\
\text { (psi) }\end{array}$ & $\begin{array}{c}\text { U.T.S. } \\
\text { (psi) }\end{array}$ & $\begin{array}{c}\% \text { elong. } \\
\text { in 1 in. }\end{array}$ \\
\hline $\begin{array}{l}\text { As welded } \\
\begin{array}{l}\text { Post-heated } \\
0.5 \text { hour } / 275^{\circ} \mathrm{C}\end{array}\end{array}$ & 130,000 & 136,500 & 11 \\
\hline
\end{tabular}


Table X. Tensile properties of $\mathrm{U}-7.5 \mathrm{w} / \mathrm{o} \mathrm{Nb}-2.5 \mathrm{w} / \mathrm{o} \mathrm{Zr}$ alloy.

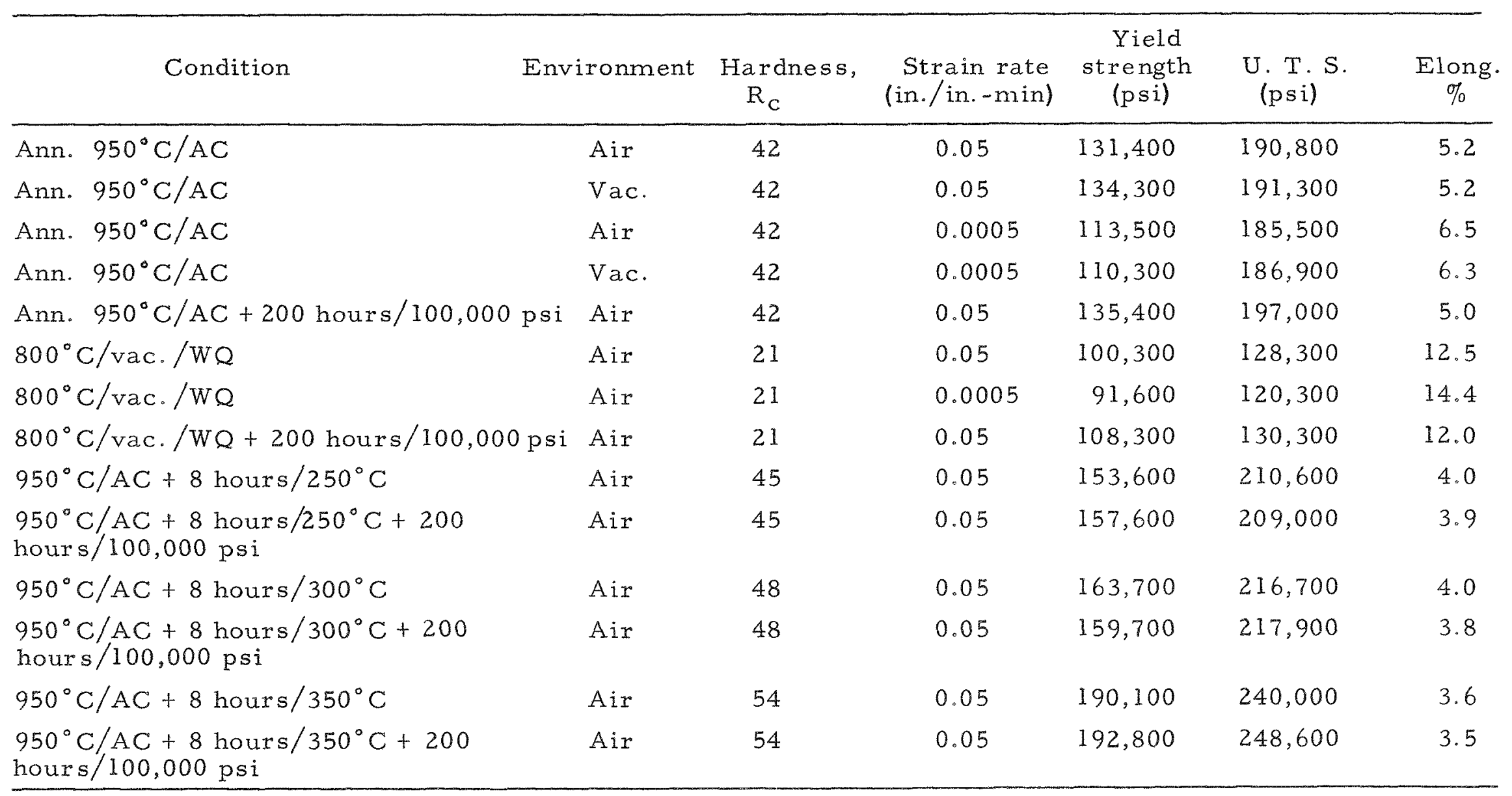

$\mathrm{AC}=$ air-cooled.

$\mathrm{WQ}=$ water - quenched. 


\section{STRUCTURE AND PHASE IDENTIFICATION}

\section{Metallography}

Individual specimens were mounted in Bakelite, ground through 180 , 320,600 , and 4-0 grit papers, and then wet-polished on a microcloth wheel with 1-micron diamond paste. The final mirror finish was given to the specimens by several hours of polishing with 0.05 -micron Linde $B$ alumina on a Syntron vibratory table covered with microcloth.

Cathodic etching was used to bring out cold-worked structures and grain boundaries of annealed and transformed structures as well as precipitates and inclusions. An electrolytic etch in phosphoric-ethylene glycol-ethyl alcohol solution was useful in giving contrast to some of the transformed structures, particularly pearlites. Polarized light is effective in identifying and photographing alpha phase, as shown in Figs。9, 10, and 11 .

\section{X-Ray Diffraction}

This method was used mainly for phase identification. When large enough in area, the metallographic samples were electropolished and this surface scanned on a General Electric XRD-5 diffractometer, using copper $\mathrm{K}_{a}$ radiation. The intensities at the various $2 \theta$ angles were recorded on a moving chart. Diffraction patterns from a quenched specimen and from one transformed at $600^{\circ} \mathrm{C}$ are shown in Figs。22 and 23 , respectively. The diffraction lines from specimens transformed at other temperatures were very broad, and for this reason no attempt was made to determine lattice parameters of the transformation products.

\section{DISCUSSION}

According to work by Dwight and Mueller ${ }^{2}$ on the ternary uraniumniobium-zirconium system, a monoeutectoid valley should occur for an alloy of the composition $\mathrm{U}-7.5 \mathrm{w} / 0 \mathrm{Nb}-2.5 \mathrm{w} / \mathrm{O} \mathrm{Zr}$ at about $638^{\circ} \mathrm{C}$. This would represent the lower boundary of the gamma phase for this alloy under equilibrium conditions. According to the present data, the conditions of the DTA determinations in this study were not near equilibrium for cooling at the rate used $\left(85^{\circ} \mathrm{C}\right.$ per hour); thus the transformation of gamma phase was depressed to $500^{\circ} \mathrm{C}$. This, however, indicates a sluggish-tomtransform 
X-Ray Diffraction Pattern of U $-7.5 \mathrm{w} / \mathrm{O} \mathrm{Nb}-2.5 \mathrm{w} / \mathrm{O} \mathrm{Zr}$

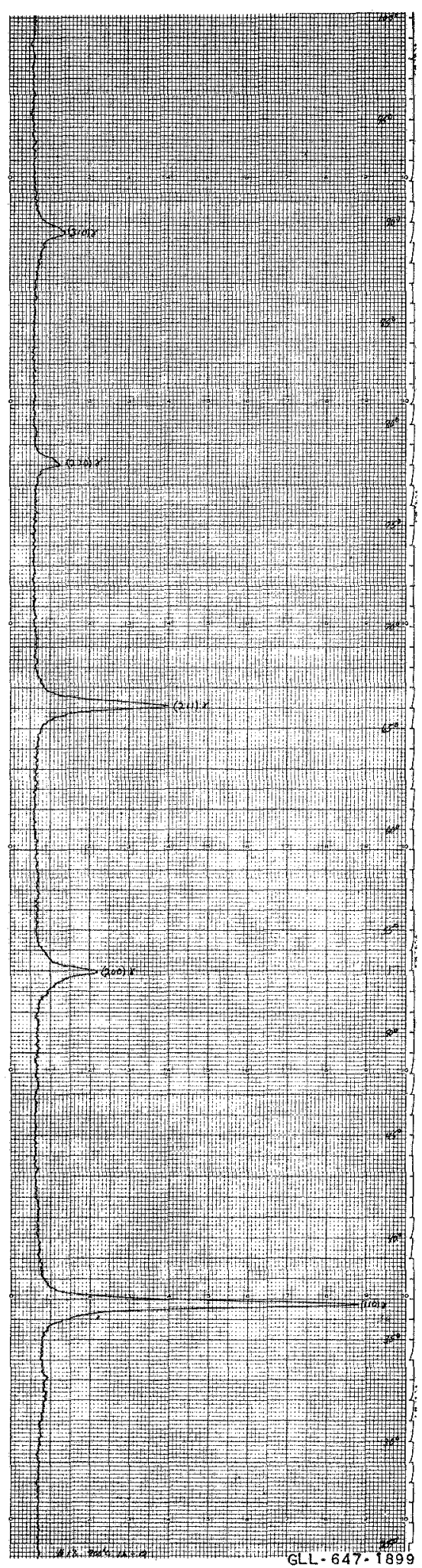

Fig. 22. Annealed at $900^{\circ} \mathrm{C}$ 1 hour and quenched. All gamma phase.

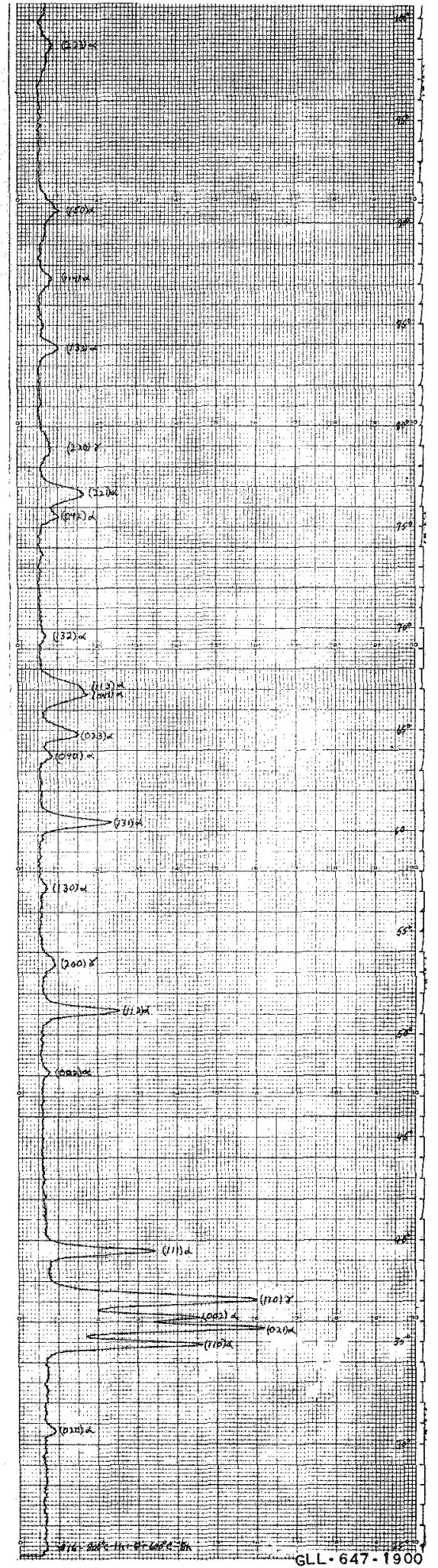

Fig. 23. Annealed at $900^{\circ} \mathrm{C}$ 1 hour and isothermally transformed 8 hours at $600^{\circ} \mathrm{C}$. Alpha and gamma phases. 
alloy that is quite gamma-stable. During heating the peak of the reaction's heat absorption is at $623^{\circ} \mathrm{C}$ and the material is all gamma at $654^{\circ} \mathrm{C}$. This is in quite good agreement with the equilibrium temperatures.

Both metallographic and $x$-ray techniques failed to detect more than one gamma phase. This indicates that the alloy avoids any miscibility gap of the gamma phases such as are present in the binary systems of uraniumniobium and uranium-zirconium。

Isothermal transformation of the gamma phase just below the critical temperature at $600^{\circ} \mathrm{C}$ proceeds by nucleation of alpha plates at grain boundaries followed by their inward growth towards the interior of the grains. The series of photographs in Appendix I illustrates this process. This pearlitic eutectoid is verified by $x$-ray diffraction to be alpha plus niobium-rich gamma $\left(\gamma^{8}\right)$. Transformation by nucleation of fine alpha within grains and grain boundaries takes place as 1 ow as $400^{\circ} \mathrm{C}$. Below $400^{\circ} \mathrm{C}$ the characteristic microstructure, high hardness, and distorted $x$-ray patterns suggest transformation is by a martensitic or shear process. The gamma phase decomposition does not occur martensitically on quenching as it does in the uranium-zirconium binary alloy because of the presence of niobium. This mechanism does operate when a low enough temperature is reached during slow cooling or isothermal aging and is due to the presence of zirconium in the alloy.

The operation of the aforementioned mechanisms of transformation offers control of the mechanical properties by various heat treatments which have been discussed. The general overall corrosion resistance of this alloy in either the gamma or transformed condition has not been a subject of this study. It is known that the alloy is not susceptible to stress-cracking. It is reasonable to believe that the gamma alloy will be more tarnish-resistant in air than the transformed alloy, based upon behavior of polished metallographic samples.

\section{CONCLUSIONS}

The incorporation of niobium and zirconium with uranium in the proportions $\mathrm{U}-7.5 \mathrm{w} / \mathrm{O} \mathrm{Nb}-2.5 \mathrm{w} / \mathrm{O} \mathrm{Zr}$ has resulted in an alloy which by judicious control of heat treatments may have a wide range of properties. A soft, ductile alloy, suitable for severe fabrication operations, is produced by gamma-annealing and quenching. It may then be strengthened to satisfactory 
strength and toughness levels by aging at various temperature levels. The alloy possesses excellent atmospheric corrosion resistance and is not subject to stress-cracking in oxygen-bearing environments.

\section{Acknowledgments}

The assistance rendered by various members of the metallurgy groups at Lawrence Radiation Laboratory in Livermore and the Bureau of Mines in Albany, Oregon, is gratefully acknowledged. Thanks are given particularly to $W$. Steele for excellent experimental work and to S. DiGiallonardo for the metallographic samples and photomicrographs. The electron micrographs were prepared by Frances Berting.

\section{REFERENCES}

I. C. A. W. Peterson,"A Study of the Isothermal Transformations of Some Binary Uranium-Base Alloys Between $400^{\circ} \mathrm{C}$ and $650^{\circ} \mathrm{C}$," Lawrence Radiation Laboratory, Livermore, Rept. UCRL-7824 (in preparation).

2. A. E. Dwight and M. H. Mueller, "Constitution of the Uranium-Rich $\mathrm{U}-\mathrm{Nb}$ and U-Nb-Zr Systems," Argonne National Laboratory Rept. ANL-558 I (1957).

3. C. A. W. Peterson and W. J. Steele, "A Study of the Effect of Alloying on the Gamma-Phase Stability of Uranium Using Vacuum Differential Thermal Analysis," Lawrence Radiation Laboratory, Livermore, Rept. UCRL-7595 (1963).

4. C. A. W. Peterson and R. R. Vandervoort, "Stress Cracking in the Uranium-10 w/o Molybdenum Alloy," Lawrence Radiation Laboratory, Livermore, Rept. UCRL-7767 (1964). 
Optical Photomicrographs and Electron Micrographs of GammaAnnealed and Isothermally Transformed U $-7.5 \mathrm{w} / \mathrm{O}$ $\mathrm{Nb}-2.5 \mathrm{w} / \mathrm{O} \mathrm{Zr}$ Alloy

TRANSFORMATION STRUCTURE OF THE ALLOY URANIUM-7 $\frac{1}{2}$ W/ONIOBIUM-2 $\frac{1}{2}$ W/O ZIRCONIUM

SPECIMEN HISTORY

Annealed at $900^{\circ} \mathrm{C}$ for I hour, aged at $600^{\circ} \mathrm{C}$ for the indicated time, and water quenched. ETCHING

Electro-etched in an orthophosphoric acid solution.

REPLICATION

Direct positive carbon with $\mathrm{Pt}-\mathrm{Pd}$ shadowing.

\section{A-MATRIX}

Niobium rich b.c.c. solid solution. B-TRANSFORMATION PRODUCT $\alpha$ Uranium. 


\section{TRANSFORMATION STRUCTURE OF THE ALLOY URANIUM-7 $\frac{1}{2}$ W/O NIOBIUM-2 $\frac{1}{2}$ W/O ZIRCONIUM}
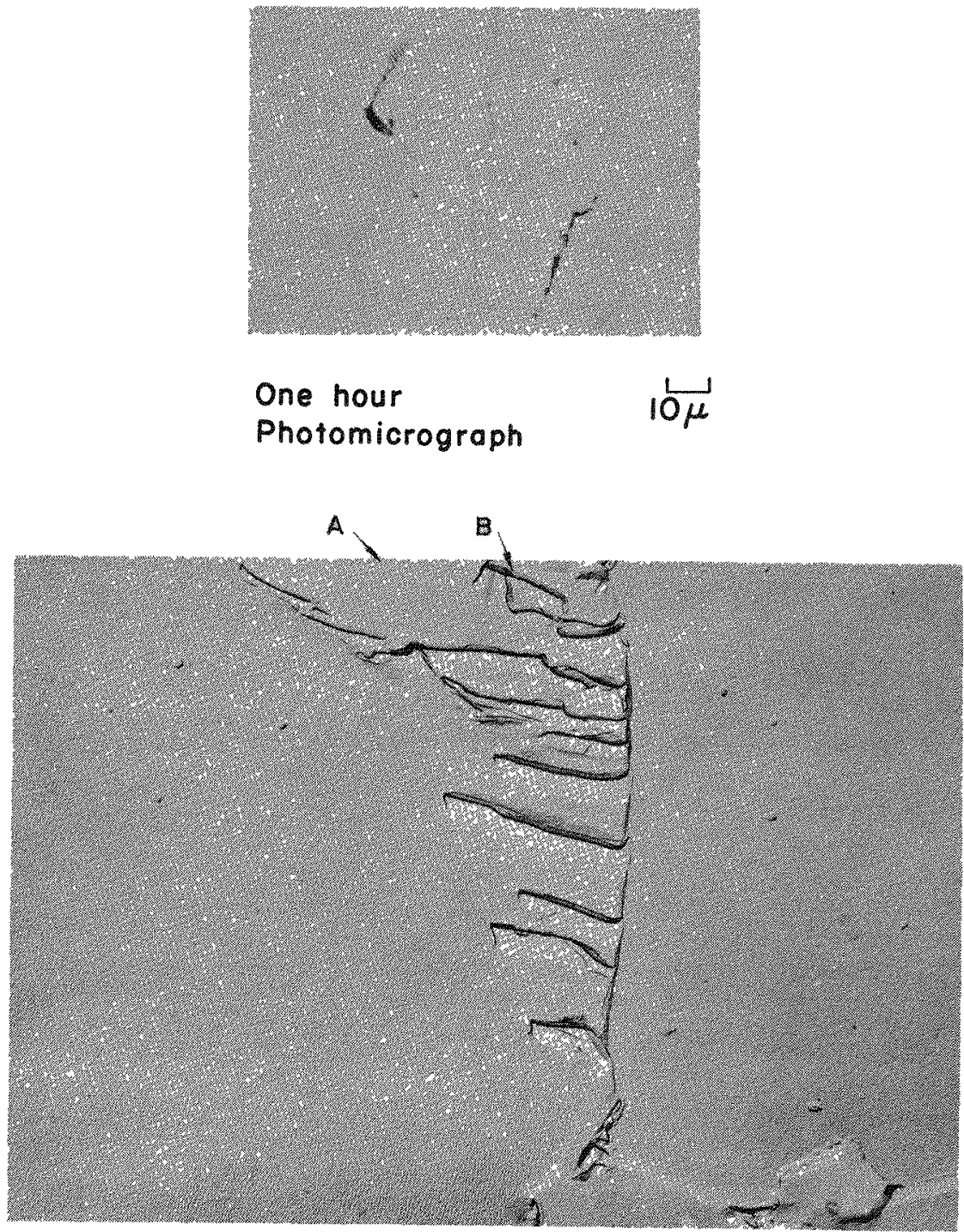

One hour

Electron micrograph 


\section{TRANSFORMATION STRUCTURE OF THE ALLOY URANIUM $-7 \frac{1}{2}$ W/O NIOBIUM $-2 \frac{1}{2}$ w/O ZIRCONIUM}

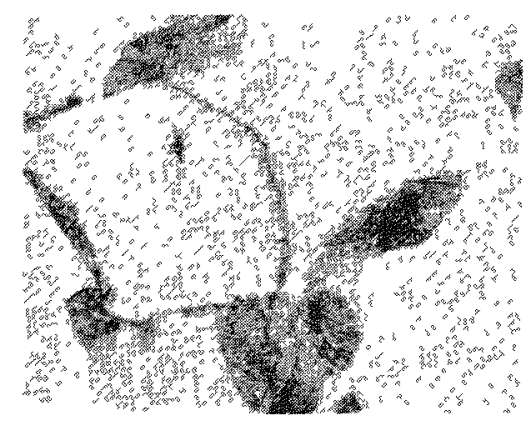

Two and one half hours $\quad \frac{L}{10 \mu}$

Photomicrograph

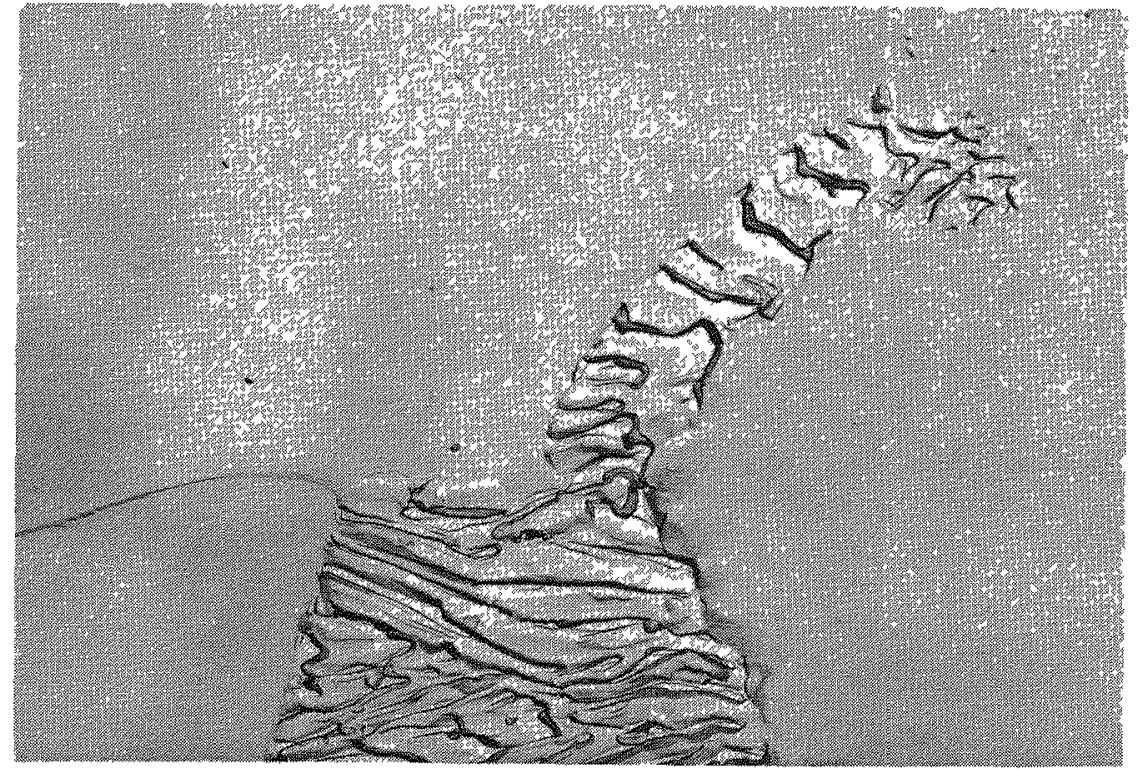

Two and one half hours

Electron micrograph 


\section{TRANSFORMATION STRUCTURE OF THE ALLOY URANIUM-7 $\frac{1}{2}$ W/O NIOBIUM-2 $\frac{1}{2}$ W/O ZIRCONIUM}

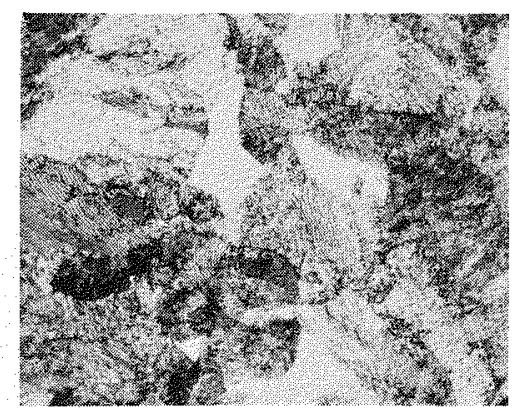

Eight hours

Photomicrograph

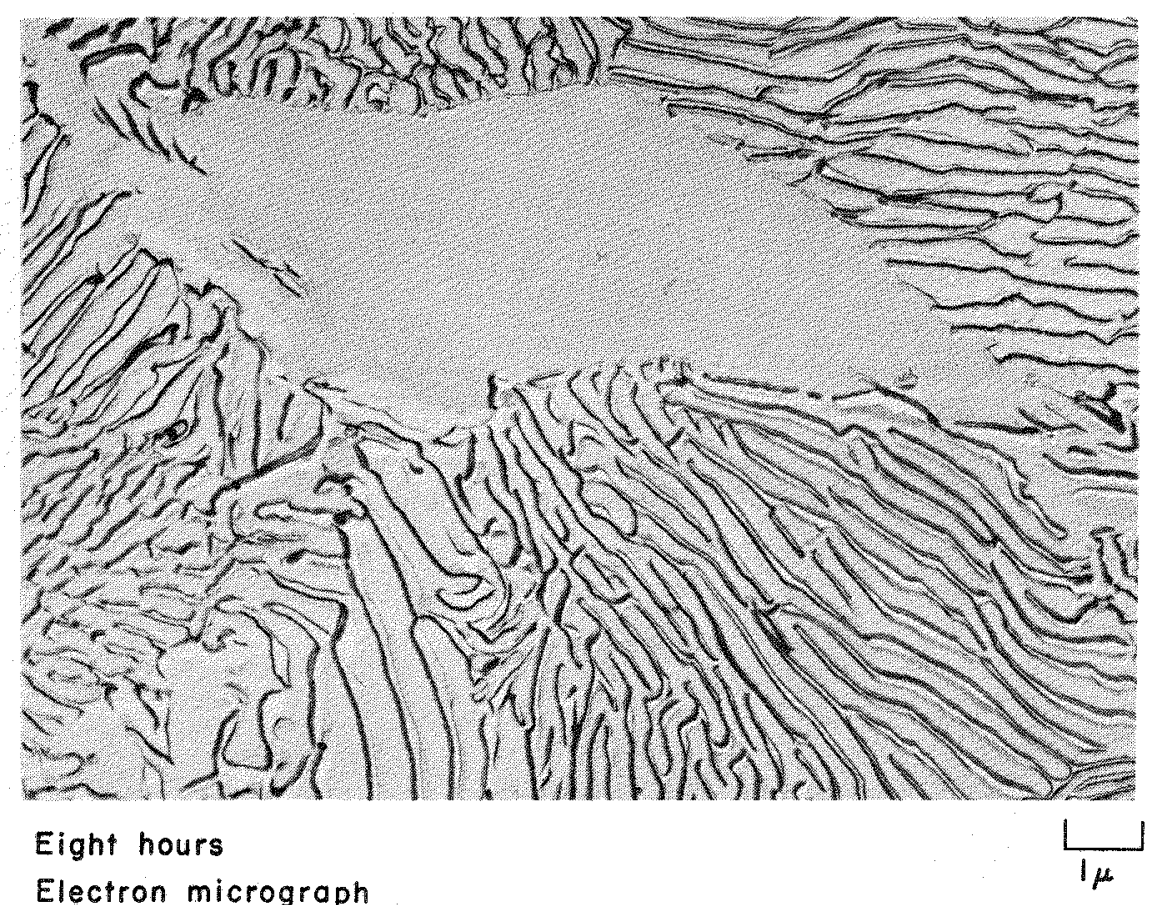


This report was prepared as an account of Government sponsored work. Neither the United States, nor the Commission, nor any person acting on behalf of the Commission:

A. Makes any warranty or representation, expressed or implied, with respect to the accuracy, completeness, or usefulness of the information contained in this report, or that the use of any information, apparatus, method, or process disclosed in this report may not infringe privately owned rights; or

B. Assumes any liabilities with respect to the use of, or for damages resulting from the use of any information, apparatus, method, or process disclosed in this report.

As used in the above, "person acting on behalf of the Commission" includes any employee or contractor of the Commission, or employee of such contractor, to the extent that such employee or contractor of the Commission, or employee of such contractor prepares, disseminates, or provides access to, any information pursuant to his employment or contract with the Commission, or his employment with such contractor. 